\title{
Grit in College Students: Associations with Achievement and Parental Influences
}

Katelyn R. Black

Follow this and additional works at: https://researchrepository.wvu.edu/etd

\section{Recommended Citation}

Black, Katelyn R., "Grit in College Students: Associations with Achievement and Parental Influences" (2014). Graduate Theses, Dissertations, and Problem Reports. 5218.

https://researchrepository.wvu.edu/etd/5218

This Thesis is protected by copyright and/or related rights. It has been brought to you by the The Research Repository @ WVU with permission from the rights-holder(s). You are free to use this Thesis in any way that is permitted by the copyright and related rights legislation that applies to your use. For other uses you must obtain permission from the rights-holder(s) directly, unless additional rights are indicated by a Creative Commons license in the record and/ or on the work itself. This Thesis has been accepted for inclusion in WVU Graduate Theses, Dissertations, and Problem Reports collection by an authorized administrator of The Research Repository @ WVU. For more information, please contact researchrepository@mail.wvu.edu. 
Grit in College Students: Associations with Achievement and Parental Influences

Katelyn R. Black, B.S.

Thesis submitted to Eberly College of Arts and Sciences and

West Virginia University

In partial fulfillment of the degree of

Master of Science in Psychology

Amy Gentzler, Ph.D., Chair

Julie Hicks Patrick, Ph.D.

Elisa Krackow, Ph.D.

Department of Psychology

Morgantown, West Virginia

2014

Keywords: academic achievement, grit, parent socialization, academic risk factors

Copyright 2014 Katelyn Black 
PARENTAL INFLUENCES OF GRIT

\begin{abstract}
Grit in College Students: Associations with Achievement and Parental Influences
\end{abstract}

Katelyn R. Black

The primary goal of this study was to investigate the relationship of Duckworth and colleagues' (2007) construct of 'grit' with academic achievement, parent socialization behaviors and beliefs, and previously established academic risk factors (e.g., low income, level of parent education). A total of 97 student-parent dyads completed online questionnaires, providing grit scores, attachment scores, the parents' grit socialization habits, and demographic information. Pearson's correlations revealed associations between student grit, GPA, and parents' reports of grit socialization. Multiple linear regressions revealed that grit uniquely predicted GPA above and beyond parent income. In addition, grit did moderate the relation between attachment and GPA.. These findings provide insight into how grit may be utilized as a protective factor in academia and socialized in the home environment. 
PARENTAL INFLUENCES OF GRIT

TABLE OF CONTENTS

Page

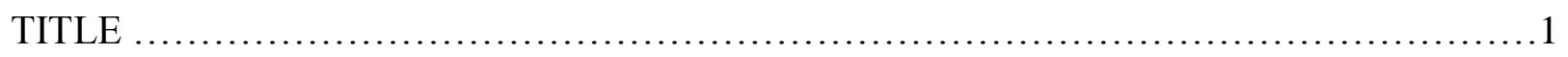

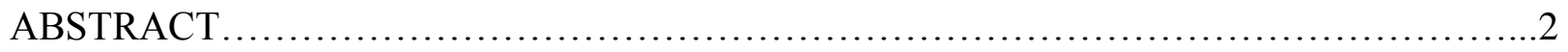

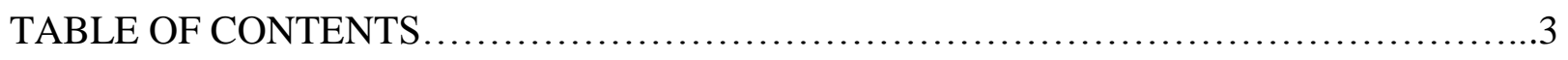

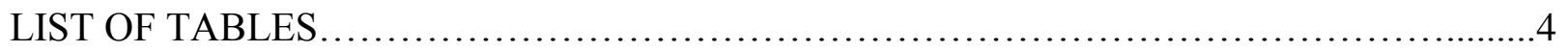

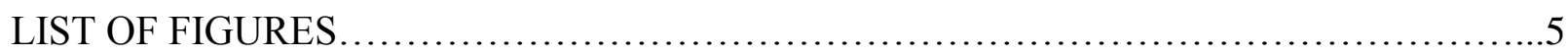

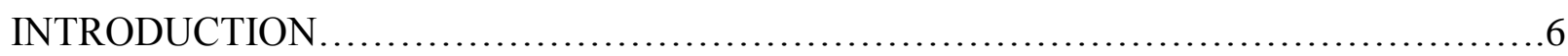

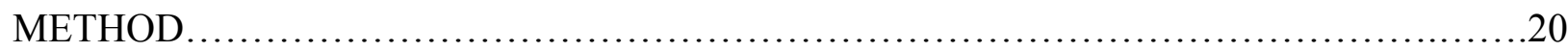

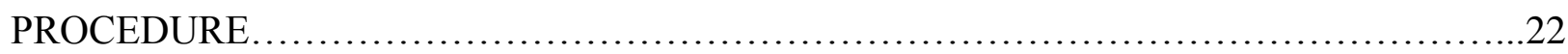

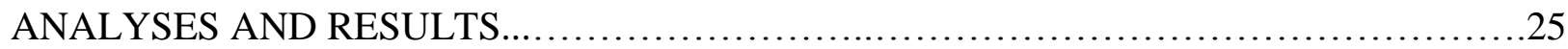

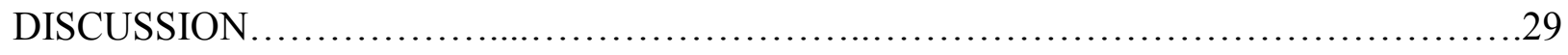

LIMITATIONS AND FUTURE DIRECTIONS....................................... 34

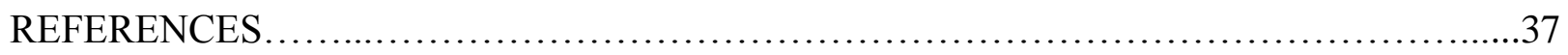

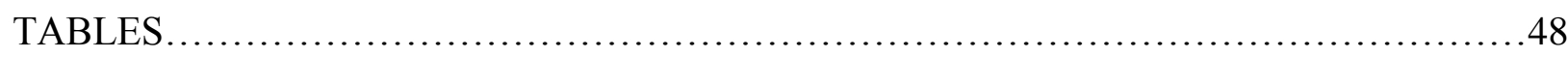

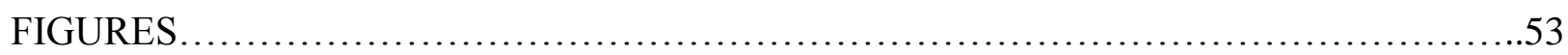

APPENDIX A, DEMOGRAPHIC INFORMATION - STUDENT PARTICIPANT..............56

APPENDIX B, DEMOGRAPHIC INFORMATION - PARENT PARTICIPANT ..............57

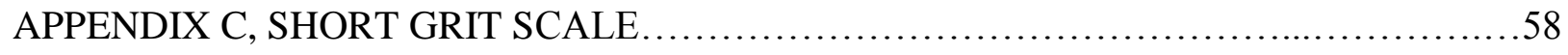

APPENDIX D, SHORT GRIT SCALE - MODERATED PARENT SOCIALIZATION.........59

APPENDIX E, EXPERIENCES IN CLOSE RELATIONSHIPS SCALE .....................61 
PARENTAL INFLUENCES OF GRIT

\section{LIST OF TABLES}

Table 1

.48

Demographic Characteristics of Student and Parent Participants

Table 2

Correlations

Table 3

Regressions for Grit and Attachment

Table 4

Regressions for Grit and Parent Education

Table 5

Regressions for Grit and Household Income 
PARENTAL INFLUENCES OF GRIT

\section{LIST OF FIGURES}

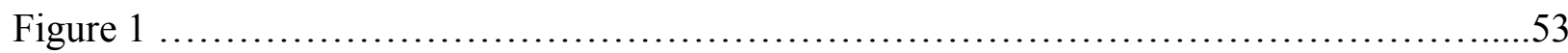

Associations between Spring GPA and attachment security score by reported grit score interaction graph.

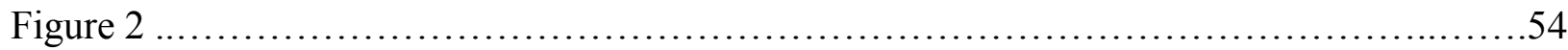
Associations between Spring GPA and parent's highest level of education by reported grit score interaction graph.

Figure 3

Associations between Spring GPA and the reported family income by reported grit score interaction graph. 
PARENTAL INFLUENCES OF GRIT

\section{Grit in College Students:}

\section{Associations with Academic Achievement and Parental Influences}

As researchers work to pinpoint positive learning attributes as well as those which may be detrimental to learning, new terminology and new concepts emerge for both protective and risk factors. Protective factors within the home environment that help to moderate the negative influence of other environmental and biological influences on academic outcomes have been extensively studied. Some of the frequently researched constructs include intrinsic motivation and goal orientation (i.e., an individual's focus of actions and attention on a specific goal with the purpose of completing said goal; Jimerson, Campos \& Greif, 2003). Goal orientation is largely related to intrinsic motivation, as one must not only set goals, but be intrinsically motivated to complete them as well. Although large body of research suggests goal orientation and intrinsic motivation may promote individuals' academic achievement (Ames \& Archer, 1986; Dweck, 1986; Eccles \& Wigfield, 2002; Elliot \& Harackiewicz, 1994; Pintrich, 2000), it is unclear whether these factors remain influential in the face of adversity or lack of progress. Grit is a protective factor similar to both of the previously mentioned positive intrinsic variables, yet is distinct. Grit is defined as an ability to overcome any level of academic abilities and skills to succeed with determination and focus even through failure (Duckworth, Peterson, Matthews \& Kelley, 2007). Duckworth and colleagues have worked to differentiate grit from other related concepts such as conscientiousness, hardiness, and intelligence.

In a series of studies, Duckworth and colleagues (2007) conducted extensive research comparing factors such as intelligence, age, and personality to measured levels of grit among various adult respondents to develop the GRIT-O scale. The samples included 1545 adults aged 25 and older reporting online, 139 Ivy League undergraduates with SAT scores averaging at 
PARENTAL INFLUENCES OF GRIT

1415, and 1218 incoming undergraduate cadets at West Point military school prior to a rigorous summer orientation training procedure. These samples varied drastically in an attempt to validate the measure across participants with different goals and different grit orientations. Online participants were individuals over the age of 25 who visited www.gritstudy.com between April 2006 and September 2006 and completed the assessment measure. It was found that grit, when controlled for education level, does increase with age, suggesting that orientation toward grit behaviors may increase with age as well. In the sample of undergraduates at an ivy-league university, undergraduates $(N=139)$ reported their cumulative GPA, SAT scores, and completed the grit measure online. It was found that students with higher grit had higher reports of cumulative GPA $(r=.25, p<.01)$, even when reported SAT scores, which were used as a measure of general mental ability, were held constant $(r=.34, p<.01)$. Similar results were seen for the West Point military cadets when grit was compared to the Whole Candidate score (a combination of high school rank, SAT scores, participation in extracurricular activities, and a physical exercise evaluation) used by West Point. Results indicated that the grit score predicted the retention of cadets after the initial summer training more so than the Whole Candidate Score (Duckworth et. al., 2007). These findings support the current study's hypothesis that GPA will be associated with students' overall grit score.

In addition to predicting grades and retention, other research suggests that those who report higher levels of grit are more apt to employ more rigorous and solitary academic habits. One study assessed study habits and overall grit scores for 190 children competing in a national spelling bee prior to the competition. Spelling bee participants self-reported their study behaviors (e.g., social vs. deliberate practice) and completed the Short GRIT scale to assess overall levels of grit. Children who performed better in the spelling bee reported higher levels of solitary, 


\section{PARENTAL INFLUENCES OF GRIT}

deliberate practice, and this habit of deliberate practice increased with spelling bee experience. Grittier spellers performed better overall and reported longer periods of self-directed study behaviors compared to those who performed worse and reported lower grit scores (Duckworth, Kirby, Tsukayama, Berstein \& Ericsson, 2011; Duckworth \& Quinn, 2009). Other research supports the link between grit and work style in that students with higher grit score were less likely to become distracted and deviate from work or work-directed behavior even when opportunities for procrastination presented themselves (Pierro, Giacomantonio, Pica, Kruglanski \& Higgins, 2011). These findings support the major premise behind grit: those students or learners who are "grittier" do not necessarily have higher IQs, but rather have higher intrinsic motivation to work above and beyond that which may be preferred or more enjoyable.

Because grit is largely a new concept, many associations between grit and other factors have yet to be explored. The primary goals of the current study are to investigate the link between grit on academic achievement, examine if grit serves as a protective factor for those with certain familial risks (e.g. insecure attachment and lower parental education), and to investigate the ways in which parents may influence grit in their college student children.

\section{Grit In Relation To Other Protective Factors}

Duckworth and colleagues (2007) define grit as an internal trait comprising a passion and determination to accomplish or maintain long-term goals. Though grit as a concept is new, early research supported the belief that humans maintain an internal trait separate from intelligence which motivates individuals to complete long-term goals (Ryans, 1939). With this belief that there is more to academics than intelligence alone, it has been hypothesized that temperament and personality traits may be more imperative to the academic achievement process than IQ or overall intelligence (Howe, 1999). There has been a large amount of research looking at these 


\section{PARENTAL INFLUENCES OF GRIT}

protective factors which help predict academic achievement above and beyond traditional risk factors such as low SES, low IQ, or low parental education. Though these factors should not be interpreted as identical to grit, they are undeniably similar the concept of grit in academia. Protective academic behaviors are perhaps best described as intrinsic motivating behaviors which help moderate negative environmental influences which may be otherwise detrimental to academic achievement. Major protective factors in education include goal orientation, hardiness, and positive parental socialization (Corpus, McClintic \& Hayenga, 2009; Hill \& Tyson, 2009; Sheard, 2009; Spera, 2005). Grit, though similar to these concepts, is not just the maintenance of a behavior but the maintenance of a behavior without reinforcement. According to Duckworth (2007), those with higher levels of grit are motivated beyond immediate outcomes and are capable of deliberately maintaining long term goals without positive result or signs of progress being necessary. In many ways, grit can be linked more closely to delay of gratification than intelligence (Duckworth et. al., 2007).

As Duckworth has moved to further develop the concept of grit and how it relates to personality, research suggests that grit most strongly relates to conscientiousness, one of the 'Big Five' personality characteristics. Conscientiousness is generally defined as a combination of factors such as dutifulness, self-discipline, deliberate practice, and orderliness (Costa \& McCrae, 1998). Conscientiousness, like grit, has also been shown to predict overall achievement in both children and adolescents in the school setting (Richardson \& Abraham, 2009; Ziegler, Knogler \& Buhner, 2009). Duckworth and colleagues defined conscientiousness as "characteristically thorough, careful, reliable, organized, industrious, and self-controlled" (2007, p. 1089). In a large sample of respondents 25 years and older, grit highly related to conscientiousness $(r=.77, p=$ $.001)$, more so than the other personality characteristics of neuroticism, agreeableness, openness 


\section{PARENTAL INFLUENCES OF GRIT}

to new experiences, and extraversion (Duckworth et. al., 2007; 2009). How then does one differentiate between grit and conscientiousness? Though conscientiousness does include perseverance and ability to refrain from distraction, Duckworth and colleagues state that conscientiousness refers to short-term intensity in the pursuance of goal completion whereas grit is better observed through long-term stamina. Those high in grit are more likely to set long-term, difficult goals without changing or modifying their planned path of action, whereas those high in conscientiousness but low in grit are more likely to set goals that are neither too easy nor too difficult. Those higher in conscientiousness rather than grit are also more likely to look for reinforcement or praise for their progress, whereas those high in grit work without praise or noticeable progress (Duckworth et. al., 2007).

Because grit is measured through goal-achieving behaviors, considering how goal orientation is related to grit is important. Though distinct from grit, goal orientation, especially when one maintains a strong sense of goal orientation can be labeled as a direct attribute within the definition of grit. However, those who report higher levels of grit are much more likely to maintain long-term and rigorous, personal goals (Duckworth et. al., 2007) whereas those individuals high in goal orientation can form their goals based responding to the needs or requirements of the environment. For instance, goal orientation can take on the form of individual-orientation or social orientation (Liem, Martin, Porter \& Colmar, 2012). Grit is solely based on individual orientation toward the completion of a goal or task. Another discerning factor between goal orientation and grit lies in what motivates general goal orientation. In a study of goal orientation in undergraduate students, three major influences on the maintenance of goal orientation were pinpointed: goal satisfaction, goal alternatives, and investment (Burkely, Anderson, Curtis \& Burkely, 2013). It was found that as these factors increased, goal 
PARENTAL INFLUENCES OF GRIT

commitment increased as well. However, those high in grit generally work with or without any

major satisfaction or indication of progress, and goal alternatives are not relevant to those high in grit. Therefore, grit is defined more so by the deliberate focus on the major goal at hand than satisfaction with the goal or the work which is being completed to achieve the goal (Duckworth et. al., 2007).

A last protective factor to be discussed in relation to grit is hardiness. Hardiness is a protective factor similar to grit through its definition of perseverance beyond negative outcomes and negative attitudes in order to achieve and survive (Maddi, Matthews, Kelley, Villareal \& White, 2012). Though this definition is similar to many aspects of grit, hardiness is distinct in that it involves particular abilities for decision-making and openness to deviating from original plans in the face of a road block. Those with high levels of hardiness are best at determining the best course of action based on the situation and changing track accordingly (Maddi et. al., 2012). In contrast, those with high grit stick to their work track despite small advancement or little positive reinforcement and generally do not deviate from the course initially established. Major, defining constructs within hardiness include control, challenge, and commitment. Those faced with adverse situations, such as undergraduate academic work, are more likely to thrive under the influence of stress or adverse situations. Hardiness is meant to be defined in this instance as an individual maintaining variable control over their effort, maintaining interest over the subject or task, and changing or thriving under the pressure (Hystad, Eid, Laberg \& Johnsen, 2009). Though maintaining a goal under adverse conditions is fitting within the definition of grit, it must still be maintained that grit differs from hardiness in many ways, as within the definition of grit there is no discussion of thriving under pressure or even enjoying the task or goal at hand, but maintaining grit and focus through the adverse effects of a long-term, difficult goal. 
PARENTAL INFLUENCES OF GRIT

In many ways, grit is undeniably related to each of these protective factors, yet still has independent components, thus making it unique. With grit being newly established as a protective factor, however, it is pertinent to investigate the ways in which grit works in conjunction with variables which have been found to be risks to academic success. For the purpose of this study, therefore, three major academic risk factors (e.g., attachment, parent income, and parent education) will be investigated in relation to grit.

\section{Academic Risk Factors}

Attachment. When initially investigating and establishing the theory of attachment, Bowlby stated his belief that a mentally healthy and capable child needed to experience a warm, intimate, and uninterrupted relationship with a caregiver (Bowlby, 1977; Bretherton, 1994). This relationship could potentially foster a mental, physical, and emotional need for the comfort and presence of the mother, and the ways in which the mother provided for these needs would establish the general 'attachment relationship'. Through the research of Ainsworth, Bowlby was able to establish the 'ideal' mother-child attachment relationship through various responses between mother and child and labeled this relationship as secure (Bretherton, 1994). A secure attachment in the infancy stage of childhood (birth to two years of age) is presently defined as a level balance between competent exploratory behaviors and proximity maintenance between the child and their mother (or attachment figure; Whipple, Bernier \& Mageau, 2011). According to attachment theory, one of the main purposes of establishing secure attachment relationships is to create a secure base for physical and mental exploration in childhood. Children with a secure attachment relationship with a parent or caretaker are predicted to be more confident in their abilities to explore the world around them and learn because the secure attachment relationship 


\section{PARENTAL INFLUENCES OF GRIT}

assures them that there is a caring and trustworthy person monitoring their safety and needs (Bowlby, 1969; 1977).

Prior research indicates that secure attachment is integral to learning and exploration. Specifically, attachment to parents has been linked to higher levels of exploration, higher inclassroom sociability, and better cognitive development (Aspelmeier \& Kerns, 2003; Elmore \& Huebner, 2010; Mikulincer, 1997). Academic achievement (e.g. grades, class participation, math and reading achievement, and advanced development of academic skills) has been linked to attachment in numerous studies (Cavendish, Neilson \& Montague, 2012; MacKay, Reynolds \& Kearney, 2010; Sim \& Ng, 2007). In addition, in a study of undergraduate students, securely attached students tended to have higher curiosity levels as well as less need for cognitive closure (having all questions about the new information answered) when new information is learned yet not thoroughly explained (Mikulincer, 1997). This implies that those with secure attachment are more open to learning new information but can tolerate ambiguity. In an additional study, Aspelmeier and Kerns (2003) tested the relationship between self-reported attachment and exploration based on participants' willingness to explore cognitively stimulating toys without any prompting or suggestion. College students who reported a secure attachment style tended to have positive attitudes toward exploring the environment and were more likely to manipulate the learning toys without prompt. In this same vein, Elliot and Reis (2003) conducted multiple studies looking at the relationship between attachment and academic achievement as well as exploratory behaviors. Securely attached students were more likely to report high academic exploration behaviors and much higher goal-mastery orientation than those who did not report secure attachment. 


\section{PARENTAL INFLUENCES OF GRIT}

A direct relation between GPA and attachment to parents has also been supported in various studies. Researchers have found that those who maintain secure attachment relationships with parents during college report higher levels of academic success through self-report of GPA and retention in their undergraduate program (Cutrona, Cole, Colangelo, Assouline \& Russel, 1994; Elmore \& Huebner, 2010; Kenny \& Donaldson, 1991). However, associations between attachment and achievement have not received unanimous empirical support. Fass and Tubman (2002) found that parent and peer attachment predicted high school GPA and certain academic behaviors, such as scholastic competence, but had no direct effect on the academic outcomes of college students.

Work productivity and general enjoyment of work in the workplace beyond adolescence and early adulthood have also been linked to attachment. Hazan and Shaver (1990) found that secure individuals ranging in age from 18-79 (mean age 39) reported that they were happier, more productive, and more involved with their daily tasks at work than avoidant or ambivalently attached individuals. Less secure individuals reported less productive habits such as oversocializing or less focus and commitment to work. Therefore, this study supports the hypothesis that attachment directly influences productivity and achievement and leads to the question of how those less secure attachments would score in an assessment of grit if they were preoccupied with obtaining or avoiding affection.

Low income and low parental education. Risk factors of poorer academic achievement in childhood and adolescence includes family of origin characteristics, such as low family income, low parental education, and parental occupation. In many cases, these three factors together can be defined as SES or social economic status (White, 1982). However, it becomes difficult to define the influence of external factors on academic achievement when SES is used 
PARENTAL INFLUENCES OF GRIT

as a bundled term. For this reason, there has been disagreement in existing literature regarding how much SES related to academic achievement. Ferguson and Ladd (1996) found that $29.5 \%$ of student achievement increases for ACT scores were solely predicted by SES characteristics such as race, parent education, and parent income. White (1982) found in investigating methods by which SES influence was measured, that there was actually a weak link between SES when analyzed as a whole variable rather than individual components predicting academic achievement. When SES is broken down into the individual components of income, education, and ethnicity, however, different results are found. Duncan, Morris, and Rodrigues (2011) found that there was a significant influence of family income on academic achievement in school-aged children, and that even an $\$ 800$ to $\$ 2200$ increase in annual income showed children reporting a $5-12 \%$ increase in academic performance. Thus, income was one of the most significant influences on academic performance of children.

When looking at both income and parent education as risk factors, even further relations are found. Davis-Kean (2005) found that income and parental education predicted student achievement (in terms of overall grades and GPA) and were linked to parents' educational expectations of their school aged children as well as their educational involvement with the child. Gutman and Eccles (1999) found a significant positive relationship between family income and GPA at both the seventh and eighth grades. There were also significant, positive relations between income and parental involvement with schooling, suggesting that parents from lowincome homes do not involve themselves in the schoolwork of their children as much as those parents with higher family income (Gutman \& Eccles, 1999). Mothers who have achieved higher levels of education also tend to have children who perform better on academic assessments of reading and math skills (Magnuson, 2007). 


\section{PARENTAL INFLUENCES OF GRIT}

Research with college students suggests that first-generation undergraduates may be at a disadvantage compared to peers raised in multi-generational college families. Stephens and colleagues (2012) found that first-generation college students, especially those from low-SES families, are raised to think in an interdependent manner in that the majority of their life choices and motivations came from working for the good of the family rather than for their own personal gain. An issue with this interdependence lies the fact that a large portion of the transition into the undergraduate years revolve around the concept of independence and living for one's own benefit and outcomes, with academic success falling entirely on the shoulders of each individual student. As a result, it has been found that interdependent first-generational college students suffer academically as a result of being unable to work for the greater purpose of family and the family unit. Rubin (2012) also completed a meta-analysis of the relation between SES and integration into college and found that those who were first generation students generally had less support from family members and were less integrated into the college setting as they were more likely to work more hours outside of school to pay college tuition. For these reasons, parental education should be considered a significant risk factor, as first-generation students may find it difficult to work within the independent college setting.

Grit and socialization of achievement behaviors. The concept of socialization is important to the current study as it has never been investigated before in relation to grit, and it may provide insight on ways in which positive academic behaviors such as grit can be nurtured within the parent-child relationship. Socialization is generally defined as the process of learning and internalizing information gathered through interactions and observations in the environment (Cooper \& Smalls, 2010; Niemiec, Lynch, Vansteenkiste, Bernstein, Deci \& Ryan, 2006). Socialization occurs through the modeling and reinforcement of behavior via interactions 
PARENTAL INFLUENCES OF GRIT

between adults and children. Bandura and McDonald (1963) originally theorized that children

learned from observing the actions and behaviors of those around them. As actions were

observed, children learned to repeat those actions in hopes of obtaining the same modeled and

desired results (Bandura \& McDonald, 1963). As children are socialized, this occurrence of

modeling will happen naturally, though it may not occur purposefully. Behaviors and actions can

also be socialized, however, through purposeful reinforcement on the part of the parent or socializer.

Reinforcement, or the periodic rewarding of a desired behavior in attempts to continue the repetition of a behavior, is used throughout socialization as a purposeful attempt to maintain positive behaviors and is used interchangeably with modeling in the socialization of children by parents (Crandall, Katkovsky \& Crandall, 1965; Ryan \& Deci, 2006). Another way to consider how socialization processes occur is through direct and indirect means, Parents may purposefully model specific behaviors that they wish to socialize or explicitly teach and scaffold these behaviors when appropriate. This would be considered socialization of behaviors or beliefs through deliberate teaching techniques. However, as parents have simple, natural interactions within the environment children will observe and internalize these behaviors and actions as well, leading to indirect socialization as well (Bugental \& Goodnow, 1998). In general, socialization can be loosely defined as the transmission of a caregiver's perceptions or world views through deliberate as well as subtle and unintentional methods (Bernardo, 2009).

Many different areas of development are socialized both directly and indirectly, such as emotional intelligence, ethnic identity, religious beliefs, academic attitudes, cognitive attitudes, and school expectations (Bernardo, 2009; Brown, Linver, Evan, DeGennaro, 2009; Neblett, Phillip, Cogburn \& Sellers, 2006). Grit as a concept has not been previously studied in regards to 


\section{PARENTAL INFLUENCES OF GRIT}

socialization. However, extensive research on the socialization of academic and cognitive behaviors may provide some insight into how grit might be socialized by parents. Cognitive socialization is defined as the manner in which parents influence the intellectual development of their students while academic socialization is found in the influence of attitudes and motives for school-based learning (Bempechat, 1992). Hill and Tyson (2009) conducted a meta-analysis of studies looking at parent-based techniques for promoting academic achievement in children and adolescents. Across the studies, even though income, parent education, and ethnicity did influence achievement, academic socialization accounted for higher academic achievement above and beyond such behaviors as helping with homework (which was negatively correlated with achievement) or active involvement with the school itself. Techniques used by parents in socializing behaviors differed across groups, but in general, children of parents with higher SES incurred more deliberate socialization, as it was found that they had more free time to dedicate to their children than those of lower SES (Hill \& Tyson, 2009).

Trends in parent socialization of academic behaviors remain constant across childhood. In a study of $4^{\text {th }}-8^{\text {th }}$ grade students, students' reports of their perceived parents academic values significantly and positively correlated with the students own academic attitudes and that this correlation continued through grade school (Masten, Juvonen, \& Spatzier, 2009). The socialization of academic attitudes continues into the undergraduate years as well. In a study of adolescent academic achievement and college performance (Niemiec et. al., 2006), students who had parents which were responsive to academic needs and socialized positive academic expectations in turn had students with more positive attitudes towards higher education. It will be valuable to research the socialization of grit by parents for a better understanding of the source of grit in the individual students. 
PARENTAL INFLUENCES OF GRIT

\section{The Present Study}

The main purpose of the study is to investigate grit in college students. This study can contribute to the limited existing research by examining student grades and studying behaviors in a sample of college freshmen. Freshmen were selected due to the fact that they are still relatively new to the college experience and may be more likely to show mixed levels of grit than those veteran students who have learned to adapt and cope with the demands of higher education. This study also examined if grit moderates the associations between established academic risks such as family income, highest level of parental education, and security of attachment with academic outcomes. Finally, this study was expected to offer new information on how grit may develop through parental influences and socialization.

Research Question 1. How does grit relate to academic achievement in undergraduates?

Hypothesis 1a. Academic grit was expected to predict overall GPA in undergraduate students, with students who score higher on grit reporting higher GPA.

Hypothesis 1b. Academic grit scores should predict amount of time spent studying. It was hypothesized that students who report greater durations of studying will also report higher grit scores.

Research Question 2. Does grit moderate the relation between academic risk factors and academic achievement?

Hypothesis 2a. Students who report higher levels of grit were expected to report higher levels of academic achievement, and securely attached students were expected to report higher grades. However, grit was also expected to moderate the influence of attachment on GPA. It is expected that a less secure attachment will significantly predict lower academic performance in undergraduates especially if lower grit scores are reported as well. However, if a student reports 
PARENTAL INFLUENCES OF GRIT

less secure attachment and higher levels of grit, attachment was expected to have less of an influence on grades.

Hypothesis $\mathbf{2 b}$. Students who report higher levels of grit were expected to report higher levels of academic achievement, regardless of their parent's level of education. In other words, parental education and grit were expected to be significantly related to GPA, but grit should moderate the impact of parental education on academic achievement. Specifically, for students with higher levels of grit, parental education should less strongly predict GPA than those students who report lower levels of grit.

Hypothesis 2c. Students who report higher levels of grit should report higher levels of academic achievement, regardless of their parent's level of income. Thus, parental income and grit were expected to be significantly related to GPA, but grit was expected to moderate the impact of parental income. Specifically, for students with higher levels of grit, parental income should less strongly predict GPA than those students who report lower levels of grit.

Research Question 3. How do parents' levels of grit and socializing behaviors influence their undergraduate student's grit levels?

Hypothesis 3a. Parents who score higher on grit were expected to have undergraduate children who report higher levels of grit.

Hypothesis $3 b$. Parents who report high socialization of grit in their children should in turn have children who report higher levels of grit.

\section{Method}

\section{Participants}

There were a total of 97 student-parent dyads analyzed for the study. A power analysis was conducted analyzing the needed power for the regression and the recommended sample size 
PARENTAL INFLUENCES OF GRIT

for a regression with three predictors at alpha level .05 with a medium power of .80 was 92

participants. Participants for this study were 97 college students and their parents (one parent per student). These student-parent dyads were selected from a larger pool of 200 undergraduate students who completed the online survey. A total of 110 students were selected for the final sample because they had a parent complete the study. However, several of the pairs of parents and students had incomplete or missing surveys, and two student participants were not enrolled for the Fall semester and thus the final sample was 97 . These 97 participants were analyzed for significant differences between the dyads with completed questionnaires. No significant differences were found.

All 97 undergraduate participants were between the ages of 18 and 19 (Mean age 18.31, S.D. $=.502)$, and were primarily Caucasian $(N=87)$. Other represented minorities were: Hispanic $(N=4)$, Black $(N=2)$, Asian-American $(N=2)$, and other $(N=2)$. The sample was also largely female $(N=77)$.

Parent participants ( 80 mothers, 17 fathers) reported an average age of $48.28(S D=5.04)$ and were largely Caucasian $(N=85)$. Other ethnicities or races reported were Hispanic $(N=5)$, Asian/Asian-American $(N=4)$, Black/African American $(N=2)$, and Native American $(N=1)$. Parent participants also reported their highest level of education, with bachelor's degree being most commonly reported $(N=27)$, followed by some college $(N=19)$, master's degree $(N=17)$, high school only $(N=14)$, associate's degree $(N=11)$, and doctoral degree $(N=9)$. Parents reported their total number of children, which ranged from 1-4 with an average of 2.4 children $(S D=.820)$. Lastly, parents reported average yearly family income. Income was reported equally across the $\$ 70,000-\$ 90,000$ and $\$ 90,000-\$ 110,000$ range ( $N=16$ for each), and was 
PARENTAL INFLUENCES OF GRIT

largely equally distributed across other ranges from $\$ 10,000$ a year to over $\$ 210,000$ a year (See Table 1).

Procedure

Data collection began in early Spring 2014 and lasted for approximately 4 weeks. The participants were freshman undergraduate students at West Virginia University. Students were recruited through the University online research system as well as through PowerPoint slide advertisements in various Psychology classes. Students were directed to an online survey website to complete the questionnaire. Prior to the start of the survey, participants were consented and granted permission for the collection of their Fall 2013 and Spring 2014 GPAs. Students also submitted the email address for one parent who would be willing to participate in the study as well. Student participants completed surveys in exchange for course credits toward their Psychology courses.

Parent participants were contacted via the email address submitted by the students. The email directed the parent to the survey site where they were able to complete the questionnaire. Parent participants were presented with an online consent form and consented to participate. Parents completed their surveys in exchange for credit for their student or for $\$ 5$ compensation.

\section{Materials}

\section{Demographic Information}

Student Demographics. Students answered a series of questions based on their demographic information. Information collected included gender, age, ethnicity, their final high school GPA, number of credit hours previously completed, a list of classes currently being taken, and the number of credit hours per class. Students also reported length of time they spent 
PARENTAL INFLUENCES OF GRIT

studying or doing school work for each class per week in estimated hours per class, and these reports were totaled for an overall 'hours spent studying' score.

Parent Demographics. Parents answered a series of questions based on their demographic information. Information collected included gender, age, ethnicity, highest levels of education completed, family income, and number of children. See Table 1.

\section{Grit Measures}

The Short Grit Scale. (GRIT-S; Duckworth \& Quinn, 2009). The Short Grit Scale assesses orientation and perseverance toward long-term goals The scale uses a 5-point Likert scale which ranges from 1 (very much like me) to 5 (not like me at all). This measure is a shortened version of the original GRIT-O measure, which had 12 items answered on the same scale (Duckworth et. al., 2007). Item-level correlations were run across the original samples in the 2007 study (West Point recruits in 2009 and 2010, Ivy League Undergraduates, and National Spelling Bee competitors) and four items were deleted from the original measure which fell below the median in prediction. This increased reliability and goodness of fit across the measure. Examples of some questions include "I have overcome setbacks to conquer an important challenge" and "New ideas and projects sometimes distract me from previous ones" Overall grit score is computed by averaging all responses. For this study, students reported their own grit ( $\alpha$ $=.77)$. In addition, parent participants reported their own personal grit $(\alpha=.73)$ and their estimate of their student's grit $(\alpha=.86)$.

Parent Socialization of Grit Measure (PSG; Black \& Gentzler, 2014). This measure, developed for the purpose of this research, served to assess the manner in which grit was socialized within the home environment by the parent as well as the parent's beliefs about the socialization of grit. Parents completed this measure based on their own socialization and 


\section{PARENTAL INFLUENCES OF GRIT}

students completed the measure based on their perceptions of their parent's socialization habits.

The measure is adapted from the original grit scale developed by Duckworth and colleagues (2007), taking each of Duckworth's items, presenting it to the participant and asking three socialization questions about each grit-measure item. Examples of these include "How strongly do you believe this in relation to your child?", "How often did you encourage this behavior?" and "How often did you model this behavior?" The higher the response score, stronger socialization behaviors and beliefs will be assumed. On this 24-question measure, the participants answered items on a five-point Likert scale ranging from 1 (I do not believe this) to 5 (I strongly believe this). Thus, higher scores indicate stronger beliefs in the socialization behavior. Good reliability was found across both the parent responses and the student responses total score. Student overall socialization measures were reliable $(\alpha=.87)$ and the subscales belief ( $\alpha=.58$ ), encourage $(\alpha=.63)$, and model $(\alpha=.64)$, had moderate reliability. The parent report of socialization had a good total score reliability $(\alpha=.88)$ and moderately reliable subscales - belief $(\alpha=.65)$, encourage $(\alpha=.65)$, and model $(\alpha=.68)$. In order to reach good reliability for the parental socialization scale, item 2 was deleted. Prior to item two being deleted, total reliability was as low as $(\alpha=.39)$. Item two did not have a negative effect on the reliability for student reports, so it was not removed from the student measure.

\section{Attachment Measures}

\section{Experiences in Close Relationships-Relationship Structures Questionnaire. (ECR-}

RS; Fraley, Heffernan, Vicary \& Brumbaugh, 2011). This 10-item questionnaire assesses attachment in adults. College student participants completed 3 versions of it to assess attachment between them and mother, father, and romantic partner. The participants answered items on a seven-point Likert scale ranging from 1 (Strongly Disagree) to 7 (Strongly Agree). Examples of 
PARENTAL INFLUENCES OF GRIT

questions within this measure include "I don't fully trust this person" (Avoidant Scale) and "I am afraid this person will abandon me" (Anxious Subscale). The participants answered this survey in regards to their anxious $(\alpha=.94)$ and avoidant $(\alpha=.80)$ attachment to their mother, their anxious $(\alpha=.93)$ and avoidant $(\alpha=.72)$ attachment to their father, and their anxious $(\alpha=.92)$ and avoidant $(\alpha=.74)$ attachment to a romantic partner with 10 items for each person. Scores were averaged across all three types of relationships for a mean score of general attachment. Participants' attachment 'security' was inferred based on the interaction term created by multiplying the anxious and avoidance subscales (after centering), per recommendation of the measure's authors (Fraley \& Bonnano, 2004). Thus, higher security would be reflected by lower anxiety and avoidance.

\section{Analyses}

Prior to conducting the main analyses for the study, checks for normality were conducted on the univariate, bivariate, and multivariate level. At the univariate level, checks for skewness and kurtosis were completed. There were no significant skews in the data and therefore no transformations were completed. There also were no significant issues found with outliers or multicollinearity. Cronbach's $\alpha$ were computed for all measures to examine reliability. All reliabilities were found to be good, if not excellent.

For Hypotheses 1 and 3, basic Pearson correlations were run to analyze relations between variables. For the three regressions needed for Hypothesis 2, three separate multiple linear hierarchical regressions were run to analyze the relation of grit and three known academic risk factors (attachment, parent education, income) in predicting academic GPA. Each regression was run similarly. In the first step of the regression model, a centered risk factor was entered as a predictor of academic achievement (GPA). In the second step for all regressions, the centered 
PARENTAL INFLUENCES OF GRIT

variable for grit was entered. Lastly, an interaction term was created by multiplying the centered variables of the risk factor and grit and in the third step; the interaction term was entered to test for any moderated effect of grit.

\section{Research Question 1: How does grit influence academic achievement in undergraduates?}

Hypothesis 1a. The hypothesis that students' academic grit scores would be related to students' GPA was assessed via a Person's $r$ correlation using students' Fall and Spring semester GPA and students' self-reported grit score. Students' spring GPA was significantly related to student grit score, $(r(95)=.275, p=.006)$. Fall GPA was not significantly correlated with the students' reported grit score $(r(95)=.13, p=.20)$.

Hypothesis 1b. The hypothesis that academic grit scores would relate to the amount of time spent studying was assessed via a Pearson's $r$ correlation. It was found that amount of time spent studying per week, as reported in hours by students, was not significantly correlated with students' reported grit score. However, this association was marginal and in the expected direction: $r(95)=.18, p=.077$.

Research Question 2: Does grit moderate the relation between academic risk factors and academic achievement?

Hypothesis 2a. To test the hypothesis that individuals who reported less secure attachment would have lower GPA, but that this relation may be moderated by self-reported grit (GRIT-S), multiple linear regression analyses were conducted. These analyses was conducted using PROCESS (Hayes, 2013) because of its inclusion of a 3-way interaction (security was indexed as the interaction term between anxiety and avoidance). When predicting Fall GPA, attachment and grit were unrelated to Fall GPA (see Table 3). When predicting Spring GPA, attachment and grit were not directly related to GPA. However, a significant 3-way interaction 
PARENTAL INFLUENCES OF GRIT

emerged (see Figure 1). Further analyses indicated at low levels of grit, the Anxiety X

Avoidance interaction was unrelated to GPA, $B=--.20, S E=.12, p=.12$. Similarly, at the mean of grit, the Anxiety X Avoidance interaction was unrelated to GPA, $B=.05, S E=.08, p=.53$. However, at high levels of grit (see the bottom panel of the Figure), the Anxiety X Avoidance interaction was significant, $B=.30, S E=.13, p=.03$. The interaction shows that students with higher grit levels, GPA was higher for those with lower levels of anxiety and avoidance (i.e., more secure individuals) compared to less secure individuals (those with higher anxiety or avoidance).

Hypothesis $2 \boldsymbol{b}$. To test the hypothesis that individuals whose parents report lower levels of education would have lower reports of academic achievement (GPA), but that this relation may be moderated by self-reported grit (GRIT-S), multiple linear regression analyses were conducted to predict overall academic achievement (See Table 4). Spring GPA was uniquely, positively predicted by both student grit as well as parent education in that students who reported higher amounts of grit or who had parents with higher levels of education also reported higher Spring GPA. However, the interaction term was non-significant $(B=.08, S E=.09, p=.35)$. The simple slopes were not significantly different from zero, indicating that parents' education level was unrelated to students' GPA for both studentswith higher levels of grit $(B=.16, S E=.07)$ as well as those with lower levels of grit $(B=.05, S E=.08)$. Overall, these findings suggest that students' grit as assessed early in the Spring Semester predicted student GPA at the end of the semester above and beyond parent education (See Figure 2).

Hypothesis 2c. To test the hypothesis that individuals whose parents report lower household income would have lower reports of academic achievement (GPA), but that this relation may be moderated by self-reported grit (GRIT-S), multiple linear regression analysis 
PARENTAL INFLUENCES OF GRIT

were conducted to predict overall academic achievement (see Table 5). For Spring GPA, students' grit positively predicted higher GPA, but family income did not significantly predict GPA, and grit did not moderate the relation between income and GPA $(B=.02, S E=.05, p=$ .34). This interaction can be seen in Figure 3. In addition, both students with higher levels of grit $(B=.03, S E=.04)$ and lower levels of grit $(B=.006, S E=.04)$, family income was unrelated to students' GPA.

\section{Research Question 3: How do parents' attitudes toward grit as well as parental socializing of grit influence the overall grit levels of undergraduate students?}

Hypothesis 3a. Using a Pearson's r correlation to analyze the relation of parents' own grit to undergraduate students' grit, no significant correlation was found, $r(95)=.17, p=.10$. This result did not support the hypothesis.

Hypothesis 3b. Parent-reported grit socializing behaviors were analyzed in relation to student-reported overall grit score via correlation coefficients. Positive, linear relations were expected between parent-report of socialization behaviors and students' grit scores. This association was found across the total parental socialization score $(r(95)=.42, p<=.001)$ as well as across all subscales of parental socialization; belief $(r(95)=.45, p<=.001)$, encouragement $(r(95)=.38, p<=.001)$, and modeling $(r(95)=.38, p<=.001)$. These findings support the hypothesis.

As an exploratory analysis, correlations were also run analyzing the relation between student-reported grit and student's report of how they believed their parents socialized grit. It was found that students' report of parental socialization was significant across the total score $(r(95)=.42, p<=.001)$ as well as across all subscales of student-reported parental socialization; belief $(r(95)=.46, p<=.001)$, encouragement $(r(95)=.39, p<=.001)$, and modeling $(r(95)=.41$, 
PARENTAL INFLUENCES OF GRIT

$p<=.001)$. Therefore, both students' and parents' reports of parental socialization behaviors were related to students' own grit levels.

\section{Discussion}

The goal of this study was to investigate links between the construct of grit and other well-established influences of academic achievement. Previously, grit was investigated as a predictor of perseverance toward long-term goals in several different studies (Duckworth et. al., 2007; Duckworth \& Gross, 2014; Duckworth \& Quinn, 2009). Although a consistent link was established, there has been little research investigating if grit may interact with other factors known to influence academic achievement and how grit may be socialized or taught. In this particular investigation, it was found that grit moderated the relation between academic achievement and the risk factors of attachment. In addition, parents' reports of their socialization were linked to students' grit, suggesting that grit may be socialized within students. Past research on grit has not previously explored the links between grit and parent socialization, and had instead linked the trait to similar internal personality characteristics such as conscientiousness (Duckworth et. al., 2007). These findings, however, suggest that the influence of parents on college students' grit is relevant, and that the behaviors and beliefs of parents could strongly influence their orientation toward perseverance for long-term goals.

\section{Grit and GPA}

One of the main focuses of this study was to look at the relation between grit and academic achievement (i.e., GPA) and the ways in which grit could influence academic outcomes. It was found that there was a significant, positive relation between grit and Spring GPA, but not Fall GPA. This finding is consistent with Duckworth's previous findings on grit's influence on academic perseverance and achievement in Ivy League and military schools 
PARENTAL INFLUENCES OF GRIT

(Duckworth et. al., 2007; Duckworth \& Quinn, 2009) where for some populations, the relations between grit and GPA were increasingly correlated over time. For this reason, students' first semester GPA may be less related to their grit than in the later, Spring semester and could be expected to increase in correlation throughout a student's entire undergraduate career.

\section{Grit as a Moderator of Academic Risk Factors}

Grit and attachment. The current study anticipated that less secure student attachment would be negatively related to student's GPA, yet moderated by the student's reported grit. The initial bivariate correlations and the regression revealed attachment was not uniquely related to student's GPA when analyzed singularly. This finding challenged a wide range of literature which suggests that secure attachment is related to positive academic outcomes including higher levels of academic achievement (Cutrona, Cole, Colangelo, Assouline, \& Russell, 1994; Fass \& Tubman, 2002), higher levels of exploration (Aspelmeier \& Kerns, 2003), better coping strategies with exam stress (Berry \& Kingswell, 2012), and better adjustment to college life (Hiester, Nordstrom, \& Swenson, 2009; Mattanah, Hancock \& Brand, 2004; Mattanah, Lopez, \& Govern, 2011). Despite the lack of direct association between attachment and GPA, as hypothesized, there was a significant moderated relationship with grit. However, specific nature of the interaction was not as expected. It was found that students who had higher reports of grit only reported higher GPA when their avoidance and anxiety scores were also low (they were more securely attached). Therefore, these findings do not support this study's novel proposal that grit may act as a buffer against academic risks surrounding less secure attachment.

Outside of this original hypothesis, exploratory correlations were run to analyze the relation between grit, attachment (both as a secure score and as individual subscales of avoidance and anxiety), and GPA. Results indicated that secure attachment and anxious attachment did not 
PARENTAL INFLUENCES OF GRIT

correlate with Fall or Spring GPA and avoidance only correlated with Spring GPA $(r(95)=-.22$, $p=.03)$. Further, attachment avoidance $(r(95)=-.25, p=.02)$ and anxiety $(r(95)=-.22, p=.00)$ were negatively related to grit, though the overall security score was not. This exploratory analysis relates to prior research which found that avoidant attached individuals tended to use work as an excuse to avoid personal relationships and interactions, but were not strong workers overall (Hazan \& Shaver, 1991). Duckworth and colleagues (2007) specifically state that 'gritty' individuals are focused on long-term goal completion with minimal distraction. Therefore it would be reasonable to conclude that avoidant individuals may be less gritty, as their main purpose in work would be to avoid others rather than complete a long-term goal. Indeed, in conjunction with the socialization findings from this study, these additional findings appear to support positive interpersonal relationships as an imperative piece of establishing and developing grit and grit behaviors.

Grit and parental education. The hypothesized relation between parents' education and students' academic achievement was clearly evident in the current study. Parents' education was associated with students' GPA. This supports previous findings that students whose parents have less education may earn lower grades (Rubin, 2012) and have a more difficult time adjusting to the demands of undergraduate life (Stephens et. al., 2012). Students of parents with less education have also been found to achieve less due to 'achievement guilt', or the realization that the student is being provided opportunities other members of the family have not been afforded (Covarrubias \& Fryberg, 2014). Recent literature promotes the utilization of positive communication techniques between the college, student, and families to close the gap between first generation and multigenerational college students (Petty, 2014), while others strongly suggest that intrinsic motivation (similar to grit) within students who come from a less-educated 


\section{PARENTAL INFLUENCES OF GRIT}

household be promoted, as it has found to be a protective factor against adjustment and achievement issues (Trevino \& DeFreitas, 2014).

Interestingly, it was found that grit did not moderate the relation between parent education and GPA, suggesting that grit does not buffer the negative effects of lower parent education. A theory behind this lack of protection from grit may lie in the fact that grit was found to be highly correlated with socialized grit beliefs and behaviors (see below), and past research has found that parents with lower levels of education tend to withdraw from positive socialization of school and school work. Contrary to popular, social beliefs, parents who have lower levels of education have been found to limit their aspirations for their children and are more likely to limit discussion of aspirations and goals (Spera, 2009). Parents with less education also have been found to withdraw from involvement with or discussions of schoolwork with their students, while reporting doubts in their ability to help their students (Kohl, Lengua \& McMahon, 2000). These parents may not have socialized their students toward positive grit beliefs and behaviors, leading to a lack of protection for students of less educated parents.

Grit and parental income. Though it was hypothesized that parent-reported family income would have a unique association with student GPA, none was found. Outside of the lack of relation between income and student GPA, it was found that grit did not moderate the relation between family income and GPA, suggesting there was a sincere lack of influence on student grades by family income for this particular sample.

These findings are especially interesting due to the fact that there is a large body of literature which supports the negative association between family income and student academic successes (Davis-Kean, 2005; Duncan, Morris \& Rodrigues, 2011; Gutman \& Eccles, 1999), though many of these studies focus on academic success in the earlier school years. Previous 


\section{PARENTAL INFLUENCES OF GRIT}

studies specifically focusing on college students have found that students who come from lowincome families tend to work more full-time hours and spend less time focused on school-related work to pay for college classes (Rubin, 2012). It is possible that financial aid provided by the university may have alleviated some of the major financial concerns of low-income students, as previous studies have found that proper financial aid provided to low-income students was strongly and positively linked to first-year student GPA (Curs \& Harper, 2012). Unfortunately, it is not possible to draw further conclusions without data on students' financial aid, and it is therefore only possible to conclude that for the study's sample, low family income was not a sizeable risk against academic achievement.

\section{Socialization of Grit and Academic Achievement}

Previously, grit was not investigated as a socialized variable related to academic achievement. The results from this study, however, indicate that parents influence academic behaviors and beliefs regarding grit and other goal-orientation behaviors. Being that both parents' reports and students' reports of parental socialization beliefs, modeling, and encouragement correlated with grit, it is strongly suggested that parents' socializing behaviors during the high school years have an impact on students' reported grit. Past research has indicated that parental socialization of academic behaviors have had a significant influence on academic grades and GPA (Cooper \& Smalls, 2009; Hill \& Tyson, 2009) and parental support was found to be indicative of later perceived college competence in students (Niemiec et. al., 2006). It is also important to note that socialization was correlated in regards to modeling, encouragement of grit behaviors, and belief in grit behaviors, meaning that various forms of grit socialization were related to reported grit. This suggests that there are various methods by which parents can both purposefully and naturally socialize grit and gritty behaviors. This has been 


\section{PARENTAL INFLUENCES OF GRIT}

supported by previous literature which found that modeling, belief discussion, and encouragement of behaviors were better suited for academic achievement than the establishment of rules and expectations alone (Fan \& Chen, 2001; Jeynes, 2007, Tyson \& Hill, 2009).

Interestingly, recent studies have suggested that parental socialization of academic beliefs and behaviors may be further broken down into specific types of academic socializations. Strambler, Linke, and Ward (2013) suggest that there are five different types of academic socializations including future-orientation, teaching-orientation, effort-orientation, shameorientation, and guilt-orientation. Their study suggested that teaching and future socialization (i.e., discussing future careers and helping students with homework) had inverse effects on student achievement, as homework help has been found to diminish independent work completion (Hill, 2001), and the future orientation was found to decrease focus from work in the present (Strambler et. al., 2013) whereas effort-orientation (i.e., reminding students they can get good grades if they try) had positive relations to academic achievement. The link between effortorientation and academic achievement is, in a way, strongly related to grit socialization. Previous studies by Dweck (1988) indicate that students who have an effort-orientation and who also had their effort-orientation promoted were more likely to report higher levels of academic achievement than peers who had orientations based on innate intelligence alone. These studies suggest that the findings of the current study are consistent with a range of related research, and this study extends this research by specifically focusing on grit.

\section{Limitations and Future Directions}

The current study shed light on the ways in which environmental, internal, and emotional factors can influence later educational outcomes in the college setting. Findings related to the socialization of grit were especially telling of how parents can and do influence grit behaviors 


\section{PARENTAL INFLUENCES OF GRIT}

and retention across long-term goals. Interestingly, however, some of the other hypotheses, which were justified based on previous literature, were not supported by the current study. Several limitations for the current study may have had an influence on these differences. Namely, the collection of data from students in the Spring semester of their freshman year may not have been ideal for the goals of the study for several reasons. First, grit is labeled as a trait of enduring and completing long-term goals. The pairing of grit data against grades from the earliest years of college may not indicate actual use of grit behaviors, as students are only beginning their long-term goal of obtaining a bachelor's degree. A longitudinal study would perhaps be ideal, as it would show changes or the lack thereof throughout the course of the program. Future studies should also aim to analyze reports of grit in relation to perseverance and retention after years within a long-term program (i.e., retention within a major, completion of the degree program) rather than by academic GPA only. This approach would be more consistent with Duckworth and colleague's' (2007) definition of grit and previous findings of grit predicting West Point cadet retention above and beyond academic GPA.

Second, the socialization questions pertained to prior behaviors, which might be biased recollections. Indeed, these recalled socialization behaviors may be related to students' current achievement (if a student is doing well in college, the parent could mistakenly assume he/she taught the child to behave in that way). Future studies should analyze socialization of college students in the context of current socialization behaviors and how parents promote grit behaviors in the present for the student. Future research should be completed to investigate grit socialization by parents for younger children as well as how parents' socialization behaviors in children longitudinally predict their later achievement in college. 
PARENTAL INFLUENCES OF GRIT

Overall, the current study provided novel insight into the ways in which grit, a relatively new concept in academia, could be linked to external influences and achievement in the college setting. Future studies directed toward parental involvement should further investigate socialization of grit-related beliefs and behaviors. Further support for parental socialization of positive academic behaviors has strong implications for the future of parents' active involvement in their children's academic achievement through the primary school years and beyond, and can inform the development of interventions for children. 
PARENTAL INFLUENCES OF GRIT

\section{References}

Ames, C., \& Archer, J. (1986). Achievement goals in the classroom: Students' learning strategies and motivation processes. Journal of Educational Psychology, 80(3), 260.

Armsden, G. C., \& Greenberg, M. T. (1987). The inventory of parent and peer attachment: Individual differences and their relationship to psychological well-being in adolescence. Journal of Youth and Adolescence, 16(5), 427-454.

Aspelmeier, J. E., \& Kerns, K. A. (2003). Love and school: Attachment/exploration dynamics in college. Journal of Social and Personal Relationships, 20(1), 5-30. doi:

\section{$10.1177 / 0265407503020001185$}

Bandura, A., \& McDonald, F. J. (1963). Influence of social reinforcement and the behavior of models in shaping children's moral judgment. The Journal of Abnormal and Social Psychology, 67(3), 274-281. doi:10.1037/h0044714

Bempechat, J. (1992). The role of parent involvement in children's academic achievement. The School Community Journal, 2(2), 31-41.

Bernardo, A. I. (2009). Filipino students' reported parental socialization of academic achievement by socioeconomic group. Psychological Reports, 105(2), 427-436. doi:10.2466/pr0.105.2.427-436

Berry, K., \& Kingswell, S. (2012). An investigation of adult attachment and coping with examrelated stress. British Journal of Guidance \& Counselling, 40(4), 315-325.

Black, K., \& Gentzler, A. (2014). Grit Socialization Survey. Unpublished measure.

Bowlby, J. (1977). The making and breaking of affectional bonds: I. Aetiology and psychopathology in the light of attachment theory. The British Journal of Psychiatry, 130201-210. doi:10.1192/bjp.130.3.201 
PARENTAL INFLUENCES OF GRIT

Bowlby, J. (1978). Attachment theory and its therapeutic implications. Adolescent Psychiatry, 65-33.

Bretherton, 1. (1994). The origins of attachment theory: John Bowlby and Mary Ainsworth. In R. D. Parke, P. A. Ornstein, J. J. Rieser, C. Zahn-Waxler (Eds.) , A century of developmental psychology (pp. 431-471). Washington, DC US: American Psychological Association. doi:10.1037/10155-029

Brown, T. L., Linver, M. R., Evans, M., \& DeGennaro, D. (2009). African-American parents' racial and ethnic socialization and adolescent academic grades: Teasing out the role of gender. Journal of Youth and Adolescence, 38(2), 214-227. doi:10.1007/s10964-008-9362-z

Bugental, D. B., \& Goodnow, J. J. (1998). Socialization processes. In W. Damon \& N. Eisenberg (Eds.), Handbook of child psychology: Social, emotional, and personality development (Vol. 3, pp. $389-462)$. New York: Wiley

Burkley, E., Anderson, D., Curtis, J., \& Burkley, M. (2013). Vicissitudes of goal commitment: Satisfaction, investments, and alternatives. Personality and Individual Differences, 54(5), 663-668. doi:10.1016/j.paid.2012.11.033

Cavendish, W., Nielsen, A. L., \& Montague, M. (2012). Parent attachment, school commitment, and problem behavior trajectories of diverse adolescents. Journal of Adolescence, 35(6), 1629-1639. doi:10.1016/j.adolescence.2012.08.001

Cooper, S. M., \& Smalls, C. (2010). Culturally distinctive and academic socialization: Direct and interactive relationships with African American adolescents' academic adjustment. Journal of Youth And Adolescence, 39(2), 199-212. doi:10.1007/s10964-009-9404-1

Corpus, J. H., McClintic-Gilbert, M., \& Hayenga, A. O. (2009). Within-year changes in children's intrinsic and extrinsic motivational orientations: Contextual predictors and 
PARENTAL INFLUENCES OF GRIT

academic outcomes. Contemporary Educational Psychology, 34(2), 154-166. doi:

10.1016/j.cedpsych.2009.01.001

Costa, P. r., \& McCrae, R. R. (1998). Six approaches to the explication of facet-level traits: Examples from conscientiousness. European Journal of Personality, 12(2), 117-134. doi:10.1002

Covarrubias, R., \& Fryberg, S. A. (2014). Movin' on up (to College): First-generation college students' experiences with family achievement guilt. Cultural Diversity and Ethnic Minority Psychology, doi:10.1037/a0037844

Crandall, V. C., Katkovsky, W., \& Crandall, V. J. (1965). Children's beliefs in their own control of reinforcements in intellectual-academic achievement situations. Child Development, 91109.

Curs, B. R., \& Harper, C. E. (2012). Financial aid and first-year collegiate GPA: A regression discontinuity approach. The Review of Higher Education, 35(4), 627-649.

Cutrona, C. E., Cole, V., Colangelo, N., Assouline, S. G., \& Russell, D. W. (1994). Perceived parental social support and academic achievement: An attachment theory perspective. Journal of Personality and Social Psychology, 66(2), 369-378. doi: $10.1037 / 0022-3514.66 .2 .369$

Davis-Kean, P. (2005). The influence of parent education and family income on child achievement: The indirect role of parental expectations and the home environment. Journal of Family Psychology, 19(2), 294-304. doi: 10.1037/0893-3200.19.2.294

Duckworth, A. L., \& Quinn, P. D. (2009). Development and validation of the short grit scale (GRIT-S). Journal of Personality Assessment, 91(2), 166-174. doi:

$10.1080 / 00223890802634290$ 
PARENTAL INFLUENCES OF GRIT

Duckworth, A. L., Kirby, T. A., Tsukayama, E., Berstein, H., \& Ericsson, K. A. (2011).

Deliberate practice spells success: Why grittier competitors triumph at the national spelling bee. Social Psychological and Personality Science, 2(2), 174-181. doi:

$10.1177 / 1948550610385872$

Duckworth, A. L., Peterson, C., Matthews, M. D., \& Kelly, D. R. (2007). Grit: Perseverance and passion for long-term goals. Journal of Personality and Social Psychology, 92(6), 10871101. doi: 10.1037/0022-3514.92.6.1087

Duckworth, A., \& Gross, J. J. (2014). Self-control and grit related but separable determinants of success. Current Directions in Psychological Science, 23(5), 319-325.

Duncan, G. J., Morris, P. A., \& Rodrigues, C. (2011). Does money really matter? Estimating impacts of family income on young children's achievement with data from randomassignment experiments. Developmental Psychology, 47(5), 1263-1279. doi: $10.1037 / \mathrm{a} 0023875$

Dweck, C. S. (1986). Motivational processes affecting learning. American Psychologist, 41(10), 1040.

Dweck, C. S. (1988). Motivation. In R. Glaser \& Lesgold (Eds.), The handbook of psychology and education (Vol. I, pp. 187- 239). Hillsdale, NJ: Erlbaum.

Eccles, J. S., \& Wigfield, A. (2002). Motivational beliefs, values, and goals. Annual Review of Psychology, 53(1), 109-132.

Elliot, A. J., \& Harackiewicz, J. M. (1994). Goal setting, achievement orientation, and intrinsic motivation: A mediational analysis. Journal of Personality and Social Psychology, 66(5), 968.

Elliot, A. J., \& Reis, H. T. (2003). Attachment and exploration in adulthood. Journal of 
PARENTAL INFLUENCES OF GRIT

Personality and Social Psychology, 85(2), 317-331. doi: 10.1037/0022-3514.85.2.317

Elmore, G. M., \& Huebner, E. S. (2010). Adolescents' satisfaction with school experiences:

Relationships with demographics, attachment relationships, and school engagement

behavior. Psychology in the Schools, 47(6), 525-537. doi: 10.1002/pits.20488

Evans, D. E., \& Rothbart, M. K. (2007). Developing a model for adult temperament. Journal of Research in Personality, 41(4), 868-888. doi:10.1016/j.jrp.2006.11.002

Fan, X., \& Chen, M. (2001). Parental involvement and students' academic achievement: A metaanalysis. Educational Psychology Review, 13(1), 1-22.

Fass, M. E., \& Tubman, J. G. (2002). The influence of parental and peer attachment on college students' academic achievement. Psychology in the Schools, 39(5), 561-574. doi:

$10.1002 /$ pits. 10050

Ferguson, R. F., \& Ladd, H. F. (1996). How and why money matters: An analysis of Alabama schools. In H. Ladd (Ed.), Holding Schools Accountable (pp. 265-298). Washington, DC: Brookings Institution.

Fraley, R. C., \& Bonanno, G. A. (2004). Attachment and loss: A test of three competing models on the association between attachment-related avoidance and adaptation to bereavement. Personality and Social Psychology Bulletin, 30(7), 878-890.

Fraley, R., Heffernan, M. E., Vicary, A. M., \& Brumbaugh, C. (2011). The experiences in close relationships—Relationship Structures Questionnaire: A method for assessing attachment orientations across relationships. Psychological Assessment, 23(3), 615-625. doi: $10.1037 / \mathrm{a} 0022898$

Gutman, L. M., \& Eccles, J. S. (1999). Financial Strain, Parenting Behaviors, and Adolescents' Achievement: Testing Model Equivalence between African American and European 
PARENTAL INFLUENCES OF GRIT

American Single-and Two-Parent Families. Child Development, 70(6), 1464-1476.

Hayes, A. F. (2013). Introduction to mediation, moderation, and conditional process analysis: a regression-based approach: Methodology in the social sciences. New York: NY: Guilford Press.

Hazan, C., \& Shaver, P. R. (1990). Love and work: An attachment-theoretical perspective. Journal of Personality and Social Psychology, 59(2), 270-280. doi:10.1037/00223514.59.2.270

Hiester, M., Nordstrom, A., \& Swenson, L. M. (2009). Stability and change in parental attachment and adjustment outcomes during the first semester transition to college life. Journal of College Student Development, 50(5), 521-538.

Hill, N. E. (2001). Parenting and academic socialization as they relate to school readiness: The roles of ethnicity and family income. Journal of Educational Psychology, 93(4), 686-697. doi:10.1037/0022-0663.93.4.686

Hill, N. E., \& Tyson, D. F. (2009). Parental involvement in middle school: A meta-analytic assessment of the strategies that promote achievement. Developmental Psychology, 45(3), 740-763. doi:10.1037/a0015362

Howe, M. J. (2001). Genius explained. Cambridge University Press.

Hystad, S. W., Eid, J., Laberg, J. C., Johnsen, B. R. H., \& Bartone, P. T. (2009). Academic stress and health: Exploring the moderating role of personality hardiness. Scandinavian Journal of Educational Research, 53(5), 421-429.

Jeynes, W. H. (2007). The relationship between parental involvement and urban secondary school student academic achievement: A meta-analysis. Urban Education, 42(1), 82-110.

Jimerson, S. R., Campos, E., \& Greif, J. L. (2003). Toward an understanding of definitions and 
PARENTAL INFLUENCES OF GRIT

measures of school engagement and related terms. The California School Psychologist, 8(1), 7-27.

Kohl, G. O., Lengua, L. J., \& McMahon, R. J. (2000). Parent involvement in school conceptualizing multiple dimensions and their relations with family and demographic risk factors. Journal of School Psychology, 38(6), 501-523.

Kenny, M. E., \& Donaldson, G. A. (1991). Contributions of parental attachment and family structure to the social and psychological functioning of first-year college students. Journal of Counseling Psychology, 38(4), 479-486. doi: 10.1037/00220167.38.4.479

Liem, G. D., Martin, A. J., Porter, A. L., \& Colmar, S. (2012). Sociocultural antecedents of academic motivation and achievement: Role of values and achievement motives in achievement goals and academic performance. Asian Journal of Social Psychology, 15(1), 1-13. doi:10.1111/j.1467-839X.2011.01351.x

MacKay, T., Reynolds, S., \& Kearney, M. (2010). From attachment to attainment: The impact of nurture groups on academic achievement. Educational and Child Psychology, 27(3), 100.

Maddi, S. R., Matthews, M. D., Kelly, D. R., Villarreal, B., \& White, M. (2012). The role of hardiness and grit in predicting performance and retention of USMA cadets. Military Psychology, 24(1), 19-28. doi: 10.1080/08995605.2012.639672

Magnuson, K. (2007). Maternal education and children's academic achievement during middle childhood. Developmental Psychology, 43(6), 1497-1512. doi: 10.1037/00121649.43.6.1497

Masten, C. L., Juvonen, J., \& Spatzier, A. (2009). Relative importance of parents and peers: Differences in academic and social behaviors at three grade levels spanning late childhood 
PARENTAL INFLUENCES OF GRIT

and early adolescence. The Journal of Early Adolescence, 29(6), 773-799. doi: $10.1177 / 0272431608325504$

Mattanah, J. F., Hancock, G. R., \& Brand, B. L. (2004). Parental attachment, separationindividuation, and college student adjustment: A structural equation analysis of mediational effects. Journal of Counseling Psychology,51(2), 213.

Mattanah, J. F., Lopez, F. G., \& Govern, J. M. (2011). The contributions of parental attachment bonds to college student development and adjustment: A meta-analytic review. Journal of Counseling Psychology, 58(4), 565.

Mikulincer, M. (1997). Adult attachment style and information processing: Individual differences in curiosity and cognitive closure. Journal of Personality and Social Psychology, 72(5), 1217-1230. doi: 10.1037/0022-3514.72.5.1217

Neblett, E. r., Philip, C. L., Cogburn, C. D., \& Sellers, R. M. (2006). African American adolescents' discrimination experiences and academic achievement: Racial socialization as a cultural compensatory and protective factor. Journal of Black Psychology, 32(2), 199-218. doi: $10.1177 / 0095798406287072$

Niemiec, C. P., Lynch, M. F., Vansteenkiste, M., Bernstein, J., Deci, E. L., \& Ryan, R. M. (2006). The antecedents and consequences of autonomous self-regulation for college: A self-determination theory perspective on socialization. Journal of Adolescence, 29(5), 761775. doi:10.1016/j.adolescence.2005.11.009

Parker, G., Tupling, H., \& Brown, L. B. (1979). Parental bonding instrument (PBI). British Journal of Medical Psychology, 52, 1-10.

Patrick, H. (1997). Social self-regulation: Exploring the relations between children's social relationships, academic self-regulation, and school performance. Educational 
PARENTAL INFLUENCES OF GRIT

Psychologist, 32(4), 209-220. doi: 10.1207/s15326985ep3204_2

Petty, T. (2014). Motivating first-generation students to academic success and college completion. College Student Journal, 48(2), 257-264

Pintrich, P. R. (2000). An achievement goal theory perspective on issues in motivation terminology, theory, and research. Contemporary Educational Psychology, 25(1), 92-104.

Richardson, M., \& Abraham, C. (2009). Conscientiousness and achievement motivation predict performance. European Journal of Personality, 23(7), 589-605. doi: 10.1002/per.732

Rubin, M. (2012). Social class differences in social integration among students in higher education: A meta-analysis and recommendations for future research. Journal of Diversity in Higher Education, 5(1), 22.

Rusk, N., \& Rothbaum, F. (2010). From stress to learning: Attachment theory meets goal orientation theory. Review of General Psychology, 14(1), 31.

Ryan, A. M., Pintrich, P. R., \& Midgley, C. (2001). Avoiding seeking help in the classroom: Who and why? Educational Psychology Review, 13(2), 93-114. doi: 10.1023/A:1009013420053

Ryan, R. M., \& Deci, E. L. (2006). Self-regulation and the problem of human autonomy: Does psychology need choice, self-determination, and will? Journal of Personality, 74(6), 15571586.

Ryans, D. G. (1939). The measurement of persistence: An historical review. Psychological Bulletin, 36(9), 715.

Sheard, M. (2009). Hardiness commitment, gender, and age differentiate university academic performance. British Journal of Educational Psychology, 79(1), 189-204.

Sim, T., \& Ng, E. (2007). Parental attachment and adjustment to higher learning institutions: The 
PARENTAL INFLUENCES OF GRIT

role of stress for a Malaysian sample of late adolescents. Journal of Counseling \& Development, 85(4), 467-474. doi:10.1002/j.1556-6678.2007.tb00615.x

Spera, C. (2005). A review of the relationship among parenting practices, parenting styles, and adolescent school achievement. Educational Psychology Review, 17(2), 125-146.

Spera, C., Wentzel, K. R., \& Matto, H. C. (2009). Parental aspirations for their children's educational attainment: Relations to ethnicity, parental education, children's academic performance, and parental perceptions of school climate. Journal of Youth and Adolescence, 38(8), 1140-1152.

Stephens, N. M., Fryberg, S. A., Markus, H. R., Johnson, C. S., \& Covarrubias, R. (2012). Unseen disadvantage: How American universities' focus on independence undermines the academic performance of first-generation college students. Journal of Personality and Social Psychology, 102(6), 1178-1197. doi: 10.1037/a0027143

Strambler, M. J., Linke, L. H., \& Ward, N. L. (2013). Academic identification as a mediator of the relationship between parental socialization and academic achievement. Contemporary Educational Psychology, 38(1), 99-106.

Trevino, N. N., \& DeFreitas, S. C. (2014). The relationship between intrinsic motivation and academic achievement for first generation Latino college students. Social Psychology of Education, 17(2), 293-306

Whipple, N., Bernier, A., \& Mageau, G. A. (2011). Broadening the study of infant security of attachment: Maternal autonomy-support in the context of infant exploration. Social Development, 20(1), 17-32. doi:10.1111/j.1467-9507.2010.00574.x

White, K. R. (1982). The relation between socioeconomic status and academic achievement. Psychological Bulletin, 91(3), 461-481. doi: 10.1037/0033-2909.91.3.461 
PARENTAL INFLUENCES OF GRIT

Ziegler, M., Knogler, M., \& Bühner, M. (2009). Conscientiousness, achievement striving, and intelligence as performance predictors in a sample of German psychology students: Always a linear relationship? Learning and Individual Differences, 19(2), 288-292. 
PARENTAL INFLUENCES OF GRIT

\begin{tabular}{|c|c|c|c|}
\hline \multicolumn{4}{|c|}{ Table 1. Demographic Characteristics of Student and Parent Participants } \\
\hline Variable & Category & $N$ & Means \\
\hline \multirow{2}{*}{ Student Age } & 18 & 65 & Mean age $=18.31$ \\
\hline & 19 & 32 & $\begin{array}{l}(S D=.502, \text { range } 18- \\
19)\end{array}$ \\
\hline \multirow[t]{3}{*}{ Parent Age } & $37-45$ & 25 & Mean age $=48.28$ \\
\hline & $46-53$ & 57 & $(S . D .=5.03$, range \\
\hline & $54-61$ & 15 & $37-61)$ \\
\hline \multirow[t]{6}{*}{ Student Ethnicity } & Black & 2 & \\
\hline & Caucasian & 87 & \\
\hline & Hispanic & 4 & \\
\hline & Native American & 0 & \\
\hline & Asian/Asian-American & 2 & \\
\hline & Other & 2 & \\
\hline \multirow[t]{5}{*}{ Parent Ethnicity } & Black & 2 & \\
\hline & Caucasian & 85 & \\
\hline & Hispanic & 5 & \\
\hline & Native American & 1 & \\
\hline & Asian/Asian-American & 4 & \\
\hline \multirow[t]{6}{*}{ Parent Education } & High school & 14 & \\
\hline & Some College & 19 & \\
\hline & Associate's Degree & 11 & \\
\hline & Bachelor's Degree & 27 & \\
\hline & Master's Degree & 17 & \\
\hline & Doctoral Degree & 9 & \\
\hline \multirow[t]{12}{*}{ Family Income } & Less than $\$ 10,000$ & 2 & \\
\hline & $\$ 10,000-\$ 30,000$ & 2 & \\
\hline & $\$ 30,000-\$ 50,000$ & 4 & \\
\hline & $\$ 50,000-\$ 70,000$ & 8 & \\
\hline & $\$ 70,000-\$ 90,000$ & 16 & \\
\hline & $\$ 90,000-\$ 110,00$ & 16 & \\
\hline & $110,000-\$ 130,000$ & 12 & \\
\hline & $\$ 130,000-\$ 150,000$ & 8 & \\
\hline & $\$ 150,000-\$ 170,000$ & 6 & \\
\hline & $\$ 170,000-\$ 190,000$ & 3 & \\
\hline & $\$ 190,000-\$ 210,000$ & 10 & \\
\hline & $\$ 210,000$ or more & 9 & \\
\hline
\end{tabular}


Table 2

Correlations

\begin{tabular}{|c|c|c|c|c|c|c|c|c|c|c|c|}
\hline Variable & $M(S D)$ & 1 & 2 & 3 & 4 & 5 & 6 & 7 & 8 & 9 & 10 \\
\hline 1. Student Grit & $3.29(.63)$ & 1 & -.07 & -.06 & .17 & $.45^{* *}$ & $.38 * *$ & $.38 * *$ & .18 & .13 & $.28 * *$ \\
\hline $\begin{array}{l}\text { 2. Parent } \\
\text { Income }\end{array}$ & $7.04(2.87)$ & & 1 & $.47 * *$ & $-.24 *$ & -.09 & -.80 & -.05 & -.10 & .02 & .04 \\
\hline $\begin{array}{ll}\text { 3. } & \text { Parent } \\
\text { Education }\end{array}$ & $4.42(1.56)$ & & & 1 & .15 & .08 & .07 & .00 & -.15 & $.24 *$ & .19 \\
\hline 4. Parental Grit & $3.74(.47)$ & & & & 1 & .12 & .12 & .15 & .14 & .08 & .05 \\
\hline $\begin{array}{l}\text { 5. Parent Soc. } \\
\text { Belief }\end{array}$ & $3.96(.54)$ & & & & & 1 & $.90 * *$ & $.85 * *$ & .05 & .12 & .12 \\
\hline $\begin{array}{l}\text { 6. Parent Soc. } \\
\text { Encourage }\end{array}$ & $3.99(.57)$ & & & & & & 1 & $.92 * *$ & .09 & .12 & .10 \\
\hline $\begin{array}{l}\text { 7. Parent Soc. } \\
\text { Model }\end{array}$ & $3.95(.59)$ & & & & & & & 1 & .06 & .07 & .06 \\
\hline $\begin{array}{l}\text { 8. Avg. Study } \\
\text { Time }\end{array}$ & $9.89(6.64)$ & & & & & & & & 1 & .00 & .02 \\
\hline 9. Fall GPA & $3.31(.68)$ & & & & & & & & & 1 & $.82 * *$ \\
\hline 10. Spring GPA & $3.13(.81)$ & & & & & & & & & & 1 \\
\hline
\end{tabular}

Note. ${ }^{*} p<.05, * * p<.01$ 
PARENTAL INFLUENCES OF GRIT

\section{Table 3}

Linear Regressions for Predicting GPA from Students' Grit and Attachment

\begin{tabular}{lcccccc}
\multicolumn{5}{c}{ Linear Regressions for Predicting GPA from Students' Grit and Attachment } \\
& \multicolumn{3}{c}{ Fall 2013 GPA } & \multicolumn{3}{c}{ Spring 2014 GPA } \\
Step 1 & $R^{2} \Delta$ & $B$ & $S E$ & $R^{2} \Delta$ & $B$ & $S E$ \\
\cline { 2 - 6 } Attachment Anxiety & .05 & & & $.18^{*}$ & & \\
Attachment Avoidance & & .09 & .11 & & .05 & .12 \\
Grit & & -.10 & .11 & -.11 & .12 \\
Anxiety X Avoidance & & .08 & .15 & .05 & .17 \\
Anxiety X Grit & -.01 & .07 & .05 & .08 \\
Avoidance X Grit & .03 & .16 & & -.06 & .18 \\
Anxiety X Avoidance X Grit & & -.15 & .15 & -.01 & .16 \\
\hline
\end{tabular}

Note. ${ }^{*} p<.05$. 
PARENTAL INFLUENCES OF GRIT

Table 4

Regressions for Grit and Parent Education

\section{Step 1}

Parent Education

Step 2

Grit

Step 3

Parent Education

Grit

Grit X Parent Education

\begin{tabular}{cccc}
\multicolumn{2}{c}{ Fall 2013 GPA } & \multicolumn{2}{c}{ Spring 2014 GPA } \\
$R^{2} \Delta$ & $\beta$ & $R^{2} \Delta$ & $\beta$ \\
\hline $.05 *$ & & .02 & .19 \\
& $.24 *$ & & \\
.06 & & $.10 * *$ & $.29 * *$ \\
& .15 & & \\
$.05 *$ & & $.10 *$ & $.20 *$ \\
& $.24 *$ & & $.27^{* *}$ \\
& .14 & & .09 \\
& .06 & &
\end{tabular}

Note. ${ }^{*} p<.05, * * p<.01$. 
PARENTAL INFLUENCES OF GRIT

\section{Table 5}

Regressions for Grit and Household Income

\section{Step 1}

Household Income

Step 2

Grit

Step 3

Household Income

Grit

Grit X Income

\begin{tabular}{cccc}
\multicolumn{2}{c}{ Fall 2013 GPA } & \multicolumn{2}{c}{ Spring 2014 GPA } \\
$R^{2} \Delta$ & $\beta$ & $R^{2} \Delta$ & $\beta$ \\
\hline-.01 & & -.01 & \\
& .02 & & .04 \\
-.00 & & $.06 * *$ & \\
& .13 & & $.29 * *$ \\
-.01 & & .05 & \\
& .03 & & .06 \\
& .13 & & $.28 * *$ \\
& -.01 & & .04
\end{tabular}

Note. $* p<.05, * * p<.01$ 
PARENTAL INFLUENCES OF GRIT

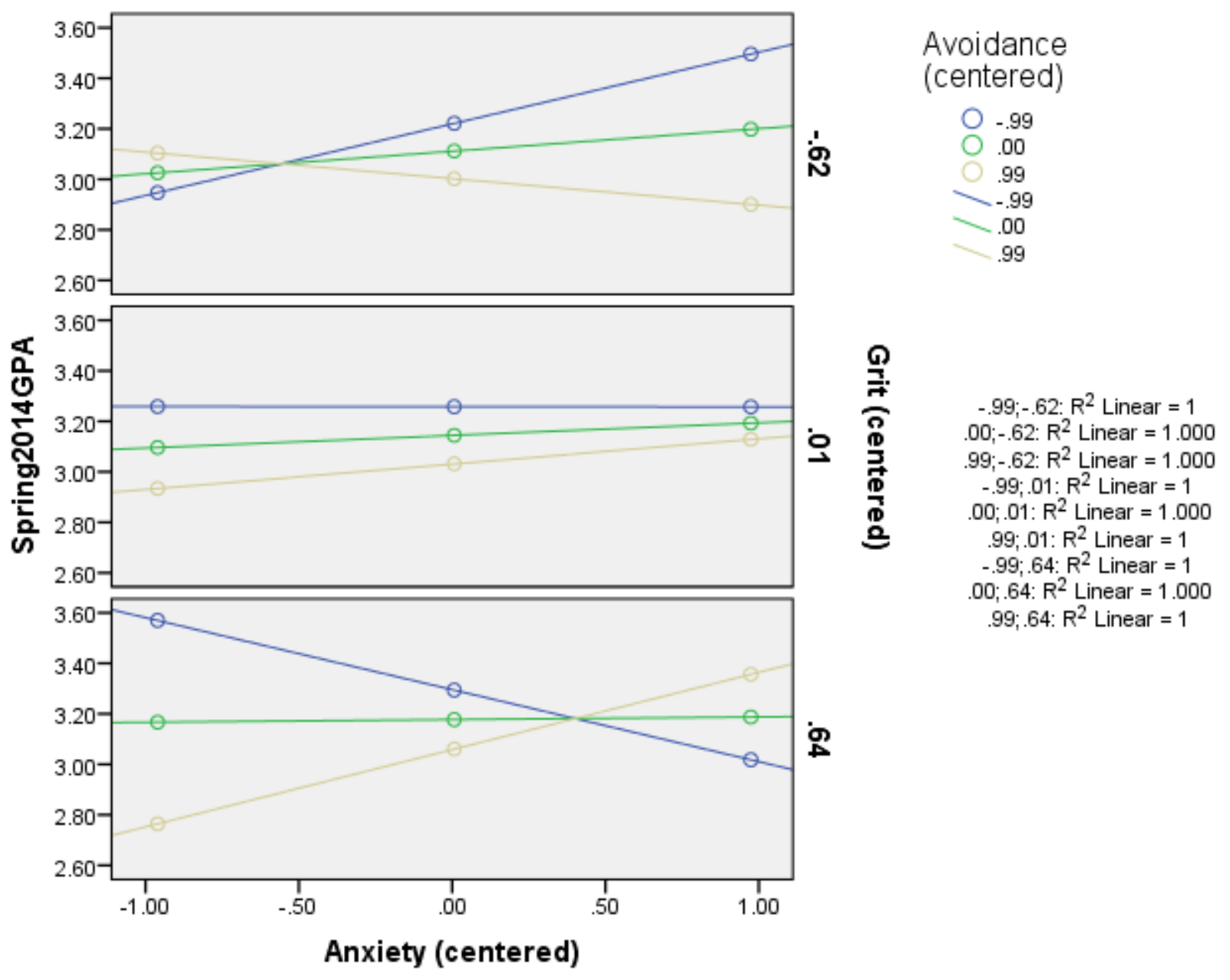

Figure 1. Predicting Spring GPA based on participants' attachment anxiety and avoidance and their self-reported grit. 
PARENTAL INFLUENCES OF GRIT

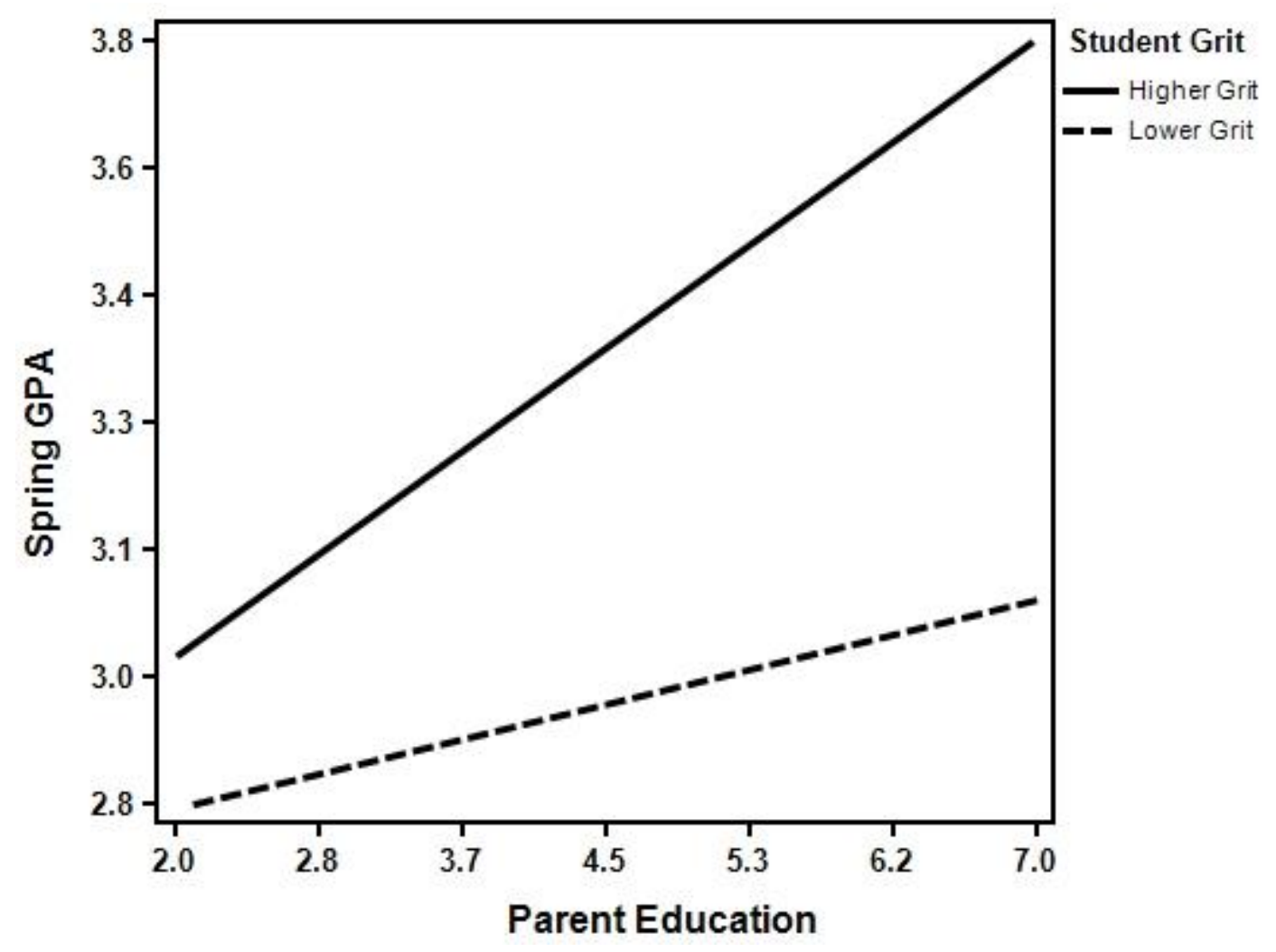

Figure 2. Associations between Spring GPA and parent's highest level of education by reported grit score interaction graph. 
PARENTAL INFLUENCES OF GRIT

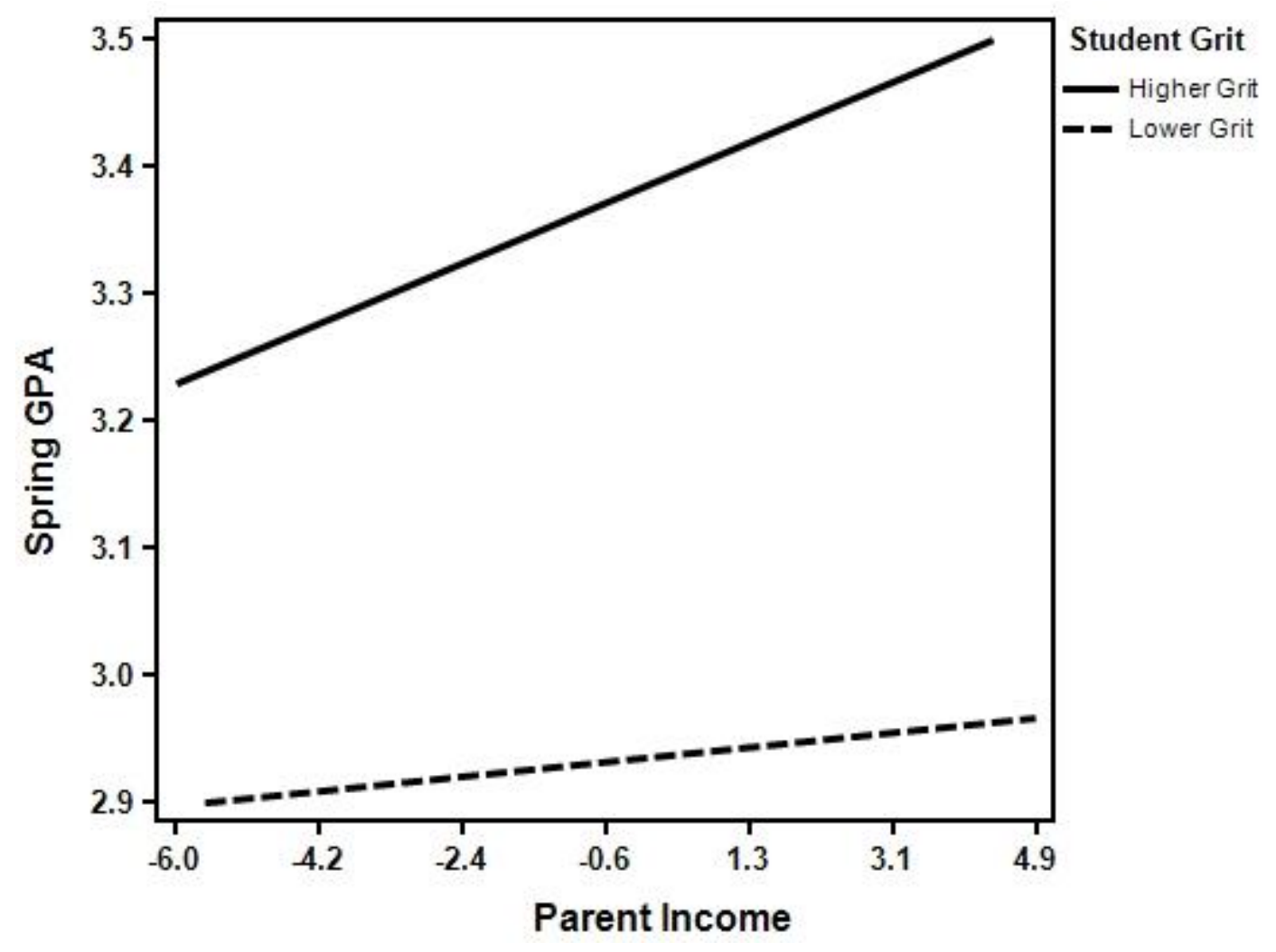

Figure 3. Associations between Spring GPA and the reported family income by reported grit score interaction graph. 
PARENTAL INFLUENCES OF GRIT

APPENDIX A

\section{Demographic Information - Student Participant}

Age:

Gender: Male Female

Major:

Student ID:

How many classes are you currently taking this semester?

Please list the classes you are taking and the number of credits per class:

\section{For EACH of the above listed classes please answer the following:}

How many minutes/hours per day do you spend studying class materials?

How many hours per day do you spend working on papers?

How many hours per day do you spend reading or doing homework?

Do you prefer working with others to complete school tasks or by yourself?
With others
By myself

What is your preferred method of study?

Fall 2013 GPA: 


\section{APPENDIX B}

\section{Demographic Information - Parent Participant}

Age:

Gender: Male Female

Number of children:

Ages of children:

Have any of your children received a college degree?

Your highest level of education completed (in years):

Yes

No

\begin{tabular}{|c|c|c|c|c|c|c|}
\hline $\mathbf{K}$ & 1 & 2 & 3 & 4 & 5 & 6 \\
\hline 7 & 8 & 9 & 10 & 11 & $\begin{array}{c}12 \\
\text { (Highschool } \\
\text { Diploma) }\end{array}$ & 13 \\
\hline 14 & 15 & 16 & 17 & 18 & 19 & 20 \\
\hline 21 & 22 & 23 & & & & \\
\hline
\end{tabular}

Highest Degree Received

Highschool Associate's Degree

Bachelor's Degree Master's Degree Doctoral Degree

Average Yearly Income (Rounded to the nearest 10k):

\begin{tabular}{|c|c|c|c|}
\hline Less than $\$ 10,000$ & $\$ 10,000-\$ 30,000$ & $\$ 30,000-\$ 50,000$ & $\$ 50,000-\$ 70,000$ \\
\hline$\$ 70,000-\$ 90,000$ & $\$ 90,000-\$ 110,000$ & $\$ 110,000-\$ 130,000$ & $\$ 130,000-\$ 150,000$ \\
\hline$\$ 150,000-\$ 170,000$ & $\$ 170,000-\$ 190,000$ & $\$ 190,000-\$ 210,000$ & $\$ 210,000$ or more. \\
\hline
\end{tabular}

On a scale ranging from 1 to 5, over the past few years, how has your household income changed?

\begin{tabular}{|c|c|c|c|c|}
\hline $\begin{array}{c}\text { Our income is } \\
\text { a lot less than } \\
\text { a few years } \\
\text { ago }\end{array}$ & $\begin{array}{c}\text { Our income is } \\
\text { slightly less } \\
\text { than a few } \\
\text { years ago }\end{array}$ & $\begin{array}{c}\text { Our income is } \\
\text { about the } \\
\text { same as a few } \\
\text { years ago }\end{array}$ & $\begin{array}{c}\text { Our income is } \\
\text { slightly more } \\
\text { than it was a } \\
\text { few years ago }\end{array}$ & $\begin{array}{c}\text { Our income is a lot more } \\
\text { than it was a few years } \\
\text { ago }\end{array}$ \\
\hline $\mathbf{1}$ & $\mathbf{2}$ & $\mathbf{3}$ & $\mathbf{4}$ & $\mathbf{5}$ \\
\hline
\end{tabular}

On a scale of 1-7, with 1 being very difficult and 7 being not difficult at all, how hard is it for you to pay your monthly bills?

\begin{tabular}{|c|c|c|c|c|c|c|}
\hline $\begin{array}{l}\text { Very } \\
\text { Difficult }\end{array}$ & & $\begin{array}{l}\text { Somewhat } \\
\text { Difficult }\end{array}$ & & & $\begin{array}{l}\text { Not } \\
\text { Difficult at } \\
\text { All }\end{array}$ \\
\hline 1 & 2 & $\mathbf{3}$ & $\mathbf{4}$ & $\mathbf{5}$ & $\mathbf{6}$ & $\mathbf{7}$ \\
\hline
\end{tabular}




\section{Short Grit Scale - Original}

\begin{tabular}{|c|c|c|c|c|c|}
\hline & $\begin{array}{c}1 \\
\text { Disagree } \\
\text { Strongly }\end{array}$ & $\begin{array}{c}2 \\
\text { Mostly } \\
\text { Disagree }\end{array}$ & $\begin{array}{c}3 \\
\text { Do Not } \\
\text { Agree or } \\
\text { Disagree }\end{array}$ & $\begin{array}{c}4 \\
\text { Mostly } \\
\text { Agree }\end{array}$ & $\begin{array}{c}5 \\
\text { Agree } \\
\text { Strongly }\end{array}$ \\
\hline $\begin{array}{l}\text { 1. New ideas and projects sometimes distract me } \\
\text { from previous ones. }\end{array}$ & 1 & 2 & 3 & 4 & 5 \\
\hline 2. Setbacks don't discourage me. & 1 & 2 & 3 & 4 & 5 \\
\hline $\begin{array}{l}\text { 3. I have been obsessed with a certain idea or } \\
\text { project for a short time but later lost interest. }\end{array}$ & 1 & 2 & 3 & 4 & 5 \\
\hline 4. I am a hard worker. & 1 & 2 & 3 & 4 & 5 \\
\hline $\begin{array}{l}\text { 5. I often set a goal but later choose to pursue a } \\
\text { different one. }\end{array}$ & 1 & 2 & 3 & 4 & 5 \\
\hline $\begin{array}{l}\text { 6. I have difficulty maintaining my focus on projects } \\
\text { that take more than a few months to complete. }\end{array}$ & 1 & 2 & 3 & 4 & 5 \\
\hline 7. I finish whatever I begin. & 1 & 2 & 3 & 4 & 5 \\
\hline 8. I am diligent. & 1 & 2 & 3 & 4 & 5 \\
\hline $\begin{array}{l}\text { 9. 3. I have been excited by a certain idea or project } \\
\text { for a short time but later lost interest. }\end{array}$ & 1 & 2 & 3 & 4 & 5 \\
\hline
\end{tabular}




\section{APPENDIX D}

\section{Short Grit Scale- Moderated Parent Socialization}

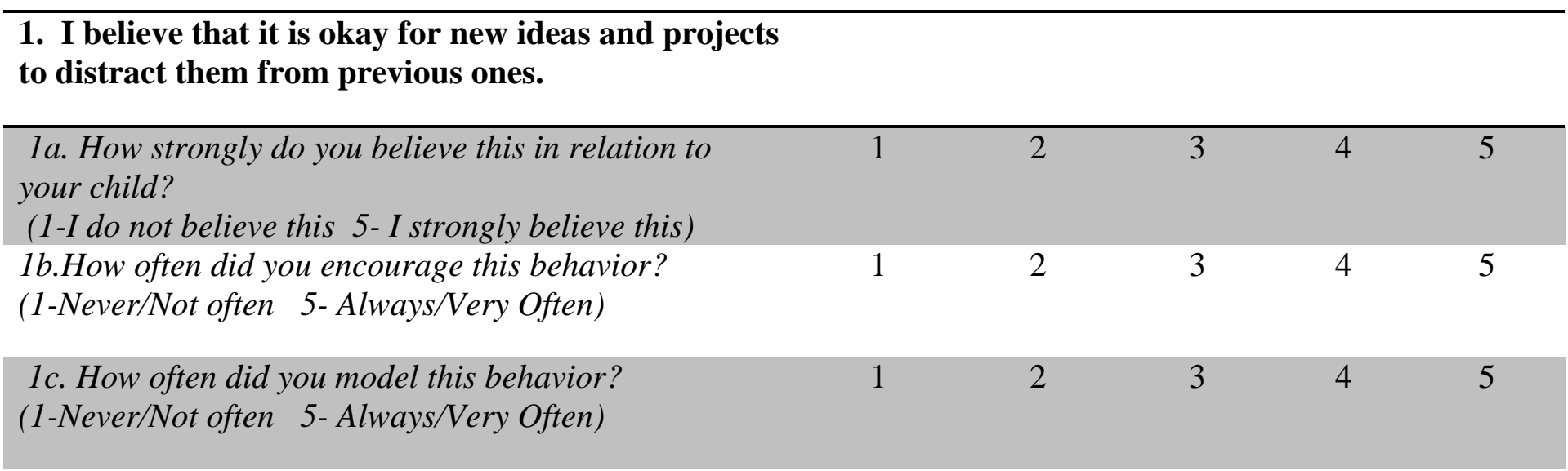

2. I believe that it is okay for new ideas and projects to distract them from previous ones.

\begin{tabular}{|c|c|c|c|c|c|}
\hline $\begin{array}{l}\text { 2a. How strongly do you believe this in relation to your } \\
\text { child? } \\
\text { (1-I do not believe this 5-I strongly believe this) }\end{array}$ & 1 & 2 & 3 & 4 & 5 \\
\hline $\begin{array}{l}\text { 2b.How often did you encourage this behavior? } \\
\text { (1-Never/Not often 5-Always/Very Often) }\end{array}$ & 1 & 2 & 3 & 4 & 5 \\
\hline $\begin{array}{l}\text { 2c. How often did you model this behavior? } \\
\text { (1-Never/Not often } 5 \text {-Always/Very Often) }\end{array}$ & 1 & 2 & 3 & 4 & 5 \\
\hline
\end{tabular}

3. I believe that it is okay to become obsessed with a certain idea or project for a short time but later lost interest.

\begin{tabular}{|c|c|c|c|c|c|}
\hline $\begin{array}{l}\text { 3a. How strongly do you believe this in relation to your } \\
\text { child? } \\
\text { (1-I do not believe this } 5 \text { - I strongly believe this) }\end{array}$ & 1 & 2 & 3 & 4 & 5 \\
\hline $\begin{array}{l}\text { 3b.How often did you encourage this behavior? } \\
\text { (1-Never/Not often 5-Always/Very Often) }\end{array}$ & 1 & 2 & 3 & 4 & 5 \\
\hline $\begin{array}{l}\text { 3c. How often did you model this behavior? } \\
\text { (1-Never/Not often 5-Always/Nery Often) }\end{array}$ & 1 & 2 & 3 & 4 & 5 \\
\hline
\end{tabular}

\section{I encouraged my child to be a hard worker.}

\begin{tabular}{|c|c|c|c|c|c|}
\hline $\begin{array}{l}\text { 4a. How strongly do you believe this in relation to your } \\
\text { child? } \\
\text { (1-I do not believe this } 5 \text { - I strongly believe this) }\end{array}$ & 1 & 2 & 3 & 4 & 5 \\
\hline $\begin{array}{l}\text { 4b.How often did you encourage this behavior? } \\
\text { (1-Never/Not often 5-Always/Very Often) }\end{array}$ & 1 & 2 & 3 & 4 & 5 \\
\hline $\begin{array}{l}\text { 4c. How often did you model this behavior? } \\
\text { (1-Never/Not often 5-Always/Very Often) }\end{array}$ & 1 & 2 & 3 & 4 & 5 \\
\hline
\end{tabular}




\section{I believe it is okay to set a goal but later choose to pursue a different one.*.}

\begin{tabular}{|c|c|c|c|c|c|}
\hline $\begin{array}{l}\text { 5a. How strongly do you believe this in relation to your } \\
\text { child? } \\
\text { (1-I do not believe this } 5 \text { - I strongly believe this) }\end{array}$ & 1 & 2 & 3 & 4 & 5 \\
\hline $\begin{array}{l}\text { 5b.How often did you encourage this behavior? } \\
\text { (1-Never/Not often 5-Always/Very Often) }\end{array}$ & 1 & 2 & 3 & 4 & 5 \\
\hline $\begin{array}{l}\text { 5c. How often did you model this behavior? } \\
\text { (1-Never/Not often 5-Always/Very Often) }\end{array}$ & 1 & 2 & 3 & 4 & 5 \\
\hline \multicolumn{6}{|l|}{$\begin{array}{l}\text { 6. I believe it is natural to have difficulty } \\
\text { maintaining focus on projects that take more than a } \\
\text { few months to complete. }\end{array}$} \\
\hline $\begin{array}{l}\text { 6a. How strongly do you believe this in relation to your } \\
\text { child? } \\
\text { (1-I do not believe this } 5 \text { - I strongly believe this) }\end{array}$ & 1 & 2 & 3 & 4 & 5 \\
\hline $\begin{array}{l}\text { 6b.How often did you encourage this behavior? } \\
\text { (1-Never/Not often 5-Always/Very Often) }\end{array}$ & 1 & 2 & 3 & 4 & 5 \\
\hline $\begin{array}{l}\text { 6c. How often did you model this behavior? } \\
\text { (1-Never/Not often 5-Always/Very Often) }\end{array}$ & 1 & 2 & 3 & 4 & 5 \\
\hline
\end{tabular}

7. I believe it is important to finish whatever you

begin.

\begin{tabular}{|c|c|c|c|c|c|}
\hline $\begin{array}{l}\text { 7a. How strongly do you believe this in relation to your } \\
\text { child? } \\
\text { (1-I do not believe this } 5 \text { - I strongly believe this) }\end{array}$ & 1 & 2 & 3 & 4 & 5 \\
\hline $\begin{array}{l}\text { 7b.How often did you encourage this behavior? } \\
\text { (1-Never/Not often 5-Always/Very Often) }\end{array}$ & 1 & 2 & 3 & 4 & 5 \\
\hline $\begin{array}{l}\text { 7c. How often did you model this behavior? } \\
\text { (1-Never/Not often 5-Always/Very Often) }\end{array}$ & 1 & 2 & 3 & 4 & 5 \\
\hline 8. I encouraged my child to be diligent. & & & & & \\
\hline $\begin{array}{l}\text { 8a. How strongly do you believe this in relation to your } \\
\text { child? } \\
\text { (1-I do not believe this } 5 \text { - I strongly believe this) }\end{array}$ & 1 & 2 & 3 & 4 & 5 \\
\hline $\begin{array}{l}\text { 8b.How often did you encourage this behavior? } \\
\text { (1-Never/Not often 5-Always/Very Often) }\end{array}$ & 1 & 2 & 3 & 4 & 5 \\
\hline $\begin{array}{l}\text { 8c. How often did you model this behavior? } \\
\text { (1-Never/Not often 5-Always/Very Often) }\end{array}$ & 1 & 2 & 3 & 4 & 5 \\
\hline
\end{tabular}


PARENTAL INFLUENCES OF GRIT

\section{APPENDIX E}

Experiences in Close Relationships-Relationship Structures Questionnaire

\begin{tabular}{|c|c|c|c|c|c|c|c|}
\hline & 1 & 2 & 3 & 4 & 5 & 6 & 7 \\
\hline & Strongly & & & Neither & & & Strongly \\
\hline & Disagree & & & Agree or & & & Agree \\
\hline & & & & Disagree & & & \\
\hline $\begin{array}{l}\text { 1. I usually discuss my problems and } \\
\text { concerns with this person. }\end{array}$ & 1 & 2 & 3 & 4 & 5 & 6 & 7 \\
\hline 2. I talk things over with this person. & 1 & 2 & 3 & 4 & 5 & 6 & 7 \\
\hline $\begin{array}{l}\text { 3. It helps to turn to this person in times of } \\
\text { need. }\end{array}$ & 1 & 2 & 3 & 4 & 5 & 6 & 7 \\
\hline 4. I find it easy to depend on this person & 1 & 2 & 3 & 4 & 5 & 6 & 7 \\
\hline $\begin{array}{l}\text { 5. I prefer not to show this person how I } \\
\text { feel deep down. }\end{array}$ & 1 & 2 & 3 & 4 & 5 & 6 & 7 \\
\hline $\begin{array}{l}\text { 6. I do not feel comfortable opening up to } \\
\text { this person. }\end{array}$ & 1 & 2 & 3 & 4 & 5 & 6 & 7 \\
\hline 7. I'm afraid this person may abandon me. & 1 & 2 & 3 & 4 & 5 & 6 & 7 \\
\hline $\begin{array}{l}\text { 8. I worry that this person won't care } \\
\text { about me as much as I care about him or } \\
\text { her. }\end{array}$ & 1 & 2 & 3 & 4 & 5 & 6 & 7 \\
\hline $\begin{array}{l}\text { 9. I often worry that this person doesn't } \\
\text { really care for me. }\end{array}$ & 1 & 2 & 3 & 4 & 5 & 6 & 7 \\
\hline 10. I don't fully trust this person. & 1 & 2 & 3 & 4 & 5 & 6 & 7 \\
\hline
\end{tabular}

